\title{
Comparative assessment of essential and heavy metals in fruits from different geographical origins
}

\author{
Malgorzata Grembecka $\cdot$ Piotr Szefer
}

Received: 19 September 2012 / Accepted: 26 April 2013 /Published online: 22 May 2013

(C) The Author(s) 2013. This article is published with open access at Springerlink.com

\begin{abstract}
The aim of this investigation was to estimate and compare essential and heavy metals contents in 98 commercially available fresh fruits from different geographic regions using multivariate techniques. The concentrations of 12 elements (calcium, magnesium, potassium, sodium, phophorus, cobalt (Co), manganese, iron, chromium $(\mathrm{Cr})$, nickel $(\mathrm{Ni})$, zinc and copper) were determined using flame atomic absorption spectrometry with deuterium-background correction. Phosphorus was determined in the form of phosphomolybdate by a spectrophotometric method. Reliability of the procedure was checked by analysis of the certified reference materials tea (NCS DC 73351), cabbage (IAEA-359) and spinach leaves (NIST-1570). Recoveries of the elements analysed varied between 85.5 and $103 \%$, and precisions for the reference materials were $0.13-6.08 \%$. Based on recommended dietary allowance and adequate intake estimated for essential elements, it was concluded that accessory fruits such as pineapples, raspberries and strawberries supply organism with the highest amounts of bioelements. Although accessory fruits were also found to be the greatest source of $\mathrm{Ni}$ among all the analysed fruits, in all the fruits $\mathrm{Ni}$ was more abundant than $\mathrm{Cr}$ and Co. Significant correlation coefficients
\end{abstract}

M. Grembecka $(\bowtie) \cdot$ P. Szefer

Department of Food Sciences,

Medical University of Gdańsk, Al. Gen. J. Hallera 107,

80-416 Gdańsk, Poland

e-mail: mgrembecka@gumed.edu.pl $(p<0.001, p<0.01$ and $p<0.05)$ were found between concentrations of some metals in fresh fruits. Application of ANOVA Kruskal-Wallis test and multivariate techniques such as factor analysis and cluster analysis enabled us to differentiate particular botanical families and types of fruits.

Keywords Mineral composition · Factor analysis · Cluster analysis $\cdot$ RDA $\cdot$ Fruits differentiation

\section{Introduction}

Fruits contain polysaccharides, sugars, vitamins, minerals and organic acids which provide their wonderful taste and excellent health properties. Fruits also contain high amounts of chemically active compounds, in particular phenolic compounds (Hui et al. 2006). The presence of antioxidants and other biologically active ingredients in fruits makes them effective in treatment of numerous diseases (Habauzit and Horcajada 2008; Kay et al. 2006; Lecerf 2008; Park et al. 2011; Tucker 2009).

At present, there is a vast diversity of edible fruits. Until recently, the availability of a fruit during the year depended on its growing season, but today, reliable transportation brings fruit of every type to our markets year-round.

Poland is the second largest producer of currants and raspberries, in the world, third in production of gooseberriess and blueberries (FAOSTAT 2010). However, in Poland, the consumption of fresh fruits 
and vegetables is decreasing. On the average in 20072009 , the consumption of fruits in households was lower by $9 \%$ than the average consumption in 2001-2003 and amounted to $41.7 \mathrm{~kg}$ person $^{-1}$ year $^{-1}$ (Nosecka 2010).

In recent years, a significant increase in the number of private, local and national food quality systems with regard to agricultural products and foodstuffs can be observed. One of the most important features of such systems is the certification process which guarantees transparency of the production process and confirmation of the characteristic features of a product (The Ministry of Agriculture and Rural Development of Poland 2010).

In the European Union (EU), fresh fruits and vegetables have been covered by the rules of the common organisation of agricultural markets. The requirements concerning the commercial quality of fresh fruits as well as detailed rules concerning the control of these products have been specified in the Commission Regulation (EC) No. 1580/2007 of 21 December 2007 (European Union 2007). Therefore, the EU Member States are obliged to carry out checks of fresh fruit at each stage of marketing. What is more, consumers expect their food to be safe and they expect access to the relevant facts to make informed choices.

Mineral components are required by every process in the human body; however, as the body cannot synthesise them, the human diet must supply regular amounts for absorption (Grembecka and Szefer 2011; Nabrzyski 2007). Unlike the macronutrients, bioelements by themselves do not contain energy. Nevertheless, metals such as copper $(\mathrm{Cu})$, zinc $(\mathrm{Zn})$ or iron $(\mathrm{Fe})$ are essential for important biochemical and physiological functions and necessary for maintaining good health throughout life (Nabrzyski 2007). They combine with certain proteins to produce enzymes that act as catalysts to help a number of body functions (Grembecka and Szefer 2011). Throughout the body, mineral components (calcium $(\mathrm{Ca})$, phosphorus $(\mathrm{P})$ and magnesium $(\mathrm{Mg})$ ) form critical structural elements, control the action of nerves and muscles, help maintain the body's water balance ( $\mathrm{Na}$ and $\mathrm{K}$ ) and buffer the $\mathrm{pH}$ of the cell and extracellular fluids (Grembecka and Szefer 2011; Nabrzyski 2007). They are also essential for the metabolism of fats, carbohydrates and the synthesis of proteins (chromium (Cr) and cobalt (Co)). Moreover, Co constitutes an integral part of vitamin $\mathrm{B}_{12}$ while manganese $(\mathrm{Mn})$ is a cofactor of such classes of enzymes as oxidoreductases, transferases, hydrolases, lyases, isomerases, ligases, lectins and integrins. Whereas $\mathrm{Cr}(\mathrm{III})$ is required in trace amounts for sugar metabolism in humans, nickel (Ni) plays numerous roles in hormonal activity, lipid metabolism, activation of some enzymes and stabilisation of DNA and RNA (Grembecka and Szefer 2011; Nabrzyski 2007). However, chronic exposure to $\mathrm{Cr}(\mathrm{VI})$ compounds can cause permanent eye injury or allergic contact dermatitis. According to IARC classification (IARC Monographs 2012), Cr(VI) and Ni are established human carcinogens while an excessively high intake of Co may damage the heart muscles and may cause an over-production of red blood cells or damage to the thyroid gland (Grembecka and Szefer 2011). Heavy metals are among major contaminants of food supply and may be considered as an important problem as among consumers there is a growing demand for safer, healthier and higher quality food. As food products cannot be entirely free from toxic elements, the sanitary inspectorates should do anything to prevent contaminated products from being available for consumers. However, it is difficult to obtain complete data concerning metal concentration in marketed fruits. There are few papers which refer only to some types of fruits, i.e. sour cherry and table grapes (Mitić et al. 2012); mangoes (Hernández-Sánchez et al. 2012); papayas (Hardisson et al. 2001a); avocado (Hardisson et al. 2001b); strawberries, grapes and cherries (Bagdatlioglu et al. 2010); apples, melons, oranges and bananas (Radwan and Salama 2006); bananas (Hardisson et al. 2001c); apples and dates (Husain et al. 1995); or apples and plums (Hamurcu et al. 2010).

Multivariate techniques have proven to be an effective statistical tool in analytical quality evaluation of food (Szefer 2007) and environmental samples (Abollino et al. 2011; Giacomino et al. 2011; Lane 2002; Webster 2001, 2007; Webster and Payne 2002). They allow on deeper exploration into possible patterns in the data set. That is why their correct application and interpretation makes them an efficient tool of classification of different products based on their mineral composition (Abollino et al. 2011; Giacomino et al. 2011). These statistical techniques are able to differentiate products both of plant and animal origin according to their type and botanical provenance as well as the level of technological processing in view of mineral composition of food products. Application of multivariate techniques for the estimate of foods quality is widely used and thoroughly presented by Arvanitoyannis and van Houwelingen-Koukaliaroglou (2003), Grembecka and Szefer (2011), Moreda-Pineiro et al. (2003), Pillonel et al. (2003), Plessi et al. (2007) and Szefer $(2003,2007)$. Although there are much data concerning statistical evaluation of plant products 
quality, only Plessi et al. (2007) used chemometrical methods to differentiate fruits and their products, i.e. berries and related jams whereas Hernández-Sánchez et al. (2012) applied support vector machines to diversification of conventional and organically cultivated mangoes.

Therefore, the aim of the present investigation was to estimate and compare essential and heavy metals contents in 98 commercially available fresh fruits from different geographic regions using multivariate techniques. Based on 12 elements concentrations, it was possible to differentiate quantitatively mineral composition of fruits samples and classify them in view of their species and type.

\section{Materials and methods}

\section{Samples}

The fresh fruits samples to be analysed were purchased from the local market in Gdańsk (Poland), but they were of Polish, European, Asian, African and American origin (see for details Table 1). All fruits were purchased from shops in Gdańsk and immediately prepared from July 2006 to December 2006. Each sample (about $1.5 \mathrm{~kg}$ ) was collected two times within the same period of harvest. They were purchased randomly in shops scattered within the city of Gdansk and in Pomeranian Voivodeship. In total, 98 products (294 analytical samples) were analysed in triplicate for macro- and microelements. A detailed characteristic of the analysed samples is presented in Table 1. Fruits are so diverse that it is difficult to devise a classification scheme that includes all known fruits. In order to arrange samples, two types of classification were applied. The first one is based on the botanical type of fruit and the second on fruits botanical family. Accessory fruits, in which some of the flesh is derived not from the ovary but from some adjacent tissue, include pineapple, raspberries and strawberries. Pomes are special kinds of accessory fruits with fleshy pulps more or less like drupes, except that they typically contain more than one seed. The best known pomes are apples and pears - in our classification, they were called pip fruits. Berry fruits are those fleshy ones produced from a single ovary. The seeds are usually embedded in the flesh of the ovary. This group of fruits consists of gooseberries, blackberries and cranberries, but banana, avocado, kiwi and papaya also belong to them. Stone fruits refer to drupe in which an outer fleshy part surrounds a shell with a seed inside. Mango, cherries and plums belong to this group (Jiang and Song 2010).

\section{Sample digestion}

The purchased fruits were firstly washed in deionised water, peeled (in case of some fruits) and dried. Then they were homogenised and dried in $60{ }^{\circ} \mathrm{C}$ until a constant mass, so content of water could be calculated. Subsequently, dry samples were again homogenised and stored until analysis in desiccators in lockable polyethylene bags. About $10.0( \pm 0.0001) \mathrm{g}$ of product portions were weighed and transferred to quartz crucibles. Samples were ashed in an electric furnace at $540{ }^{\circ} \mathrm{C}$ with gradual increase in temperature. Next, $1.5 \mathrm{~mL}$ of $36.5 \% \mathrm{HCl}$ (Tracepur ${ }^{\circledR}$ Merck) and $0.05 \mathrm{~mL}$ of $65 \% \mathrm{HNO}_{3}$ (Suprapur ${ }^{\circledR}$ Merck) were added to quartz crucible with digested sample. Subsequently, it was placed on a water bath until evaporation of acids. Then, $1.5 \mathrm{~mL}$ of $36.5 \% \mathrm{HCl}$ (Tracepur ${ }^{\circledR}$ Merck) was added to the residue, and crucible covered with a watch glass was heated $1 \mathrm{~min}$ on the water bath. Every digested sample was dissolved up to $25 \mathrm{~mL}$ with ultra-pure water $\left(18.2 \mathrm{M} \Omega \mathrm{cm}^{-1}\right)$ from a Milli-Q system (Millipore, MA) (Grembecka et al. 2007).

\section{Elements analyses}

The concentrations of elements $(\mathrm{Mg}, \mathrm{Ca}$, potassium $(\mathrm{K})$, sodium $(\mathrm{Na}), \mathrm{Zn}, \mathrm{Cu}, \mathrm{Fe}, \mathrm{Cr}, \mathrm{Co}, \mathrm{Ni}$ and $\mathrm{Mn}$ ) were determined in an air-acetylene flame atomic absorption spectrometer using deuterium-background correction. A Philips PU-9100× (Philips, Great Britain) model atomic absorption spectrometer was used for metal analyses. In all cases, stoichiometric flame air/acetylene was used with the fuel flow of $1.0 \mathrm{~L} / \mathrm{min}$ (Grembecka et al. 2007). In the case of $\mathrm{Na}$ and $\mathrm{K}$ determinations, cesium chloride (Merck, Darmstadt, Germany) was added to samples and standards, as an ionisation buffer at a concentration of $0.2 \%(w / v)$ and in the case of $\mathrm{Ca}$ and $\mathrm{Mg}$ measurements, Lanthanum(III) oxide (Merck, Darmstadt, Germany) was used as a releasing agent at a concentration of $0.4 \%(w / v)$. P was determined in the form of phosphomolybdate by spectrophotometric method (Official Methods of Analysis of AOAC International 2002) using Spekol 11 (Carl Zeiss, Jena, Germany). 
Table 1 Characteristics of the analysed products

\begin{tabular}{|c|c|c|c|c|}
\hline Product & Type of fruit & Origin & Botanical family & Scientific name \\
\hline Apple Antonovka & Pip fruits & Poland & Rosaceae & $\begin{array}{l}\text { Malus domestica Borkh. } \\
\text { 'Antonovka' }\end{array}$ \\
\hline Apple Cortland & Pip fruits & Poland & Rosaceae & M. domestica Borkh. 'Cortland' \\
\hline Apple Granny Smith & Pip fruits & Holland & Rosaceae & Malus 'Granny Smith' \\
\hline Apple Idared & Pip fruits & Poland & Rosaceae & M. domestica Borkh. 'Idared' \\
\hline Apple Jonagold & Pip fruits & Poland & Rosaceae & M. domestica 'Jonagold' \\
\hline Apple Lobo & Pip fruits & Poland & Rosaceae & M. domestica Borkh. 'Lobo' \\
\hline Avocado & Berry fruits & Dominican Republic & Lauraceae & Persea americana \\
\hline Avocado & Berry fruits & Israel & Lauraceae & P. americana \\
\hline Avocado & Berry fruits & Spain & Lauraceae & P. americana \\
\hline Banana & Berry fruits & Costa Rica & Musaceae & Musa L. \\
\hline Banana & Berry fruits & Ecuador & Musaceae & Musa L. \\
\hline Blueberry & Berry fruits & Poland & Ericaceae & Vaccinium myrtillus \\
\hline Blackcurrant & Berry fruits & Poland & Grossulariaceae & Ribes nigrum \\
\hline Cherry (gean; black) & Stone fruits & Poland & Rosaceae & Prunus avium \\
\hline Cherry & Stone fruits & Poland & Rosaceae & Prunus cerasus \\
\hline Cherry (gean) & Stone fruits & Poland & Rosaceae & P. avium \\
\hline Cranberry & Berry fruits & Poland & Ericaceae & Vaccinium oxycoccos \\
\hline Gooseberry & Berry fruits & Poland & Grossulariaceae & Ribes uva-crispa \\
\hline Grapefruit (red) & Berry fruits & Spain & Rutaceae & Citrus paradisi Macfad. \\
\hline Grapefruit (white) & Berry fruits & Turkey & Rutaceae & C. paradisi Macfad. \\
\hline Grapefruit & Berry fruits & Israel & Rutaceae & C. paradisi Macfad. \\
\hline Grapes (black) & Berry fruits & Italy & Vitaceae & Vitis vinifera \\
\hline Grapes (black) & Berry fruits & Poland & Vitaceae & $V$. vinifera \\
\hline Grapes (black) & Berry fruits & Spain & Vitaceae & V. vinifera \\
\hline Grapes (crimson) & Berry fruits & Italy & Vitaceae & $V$. vinifera \\
\hline Grapes (pink) & Berry fruits & Italy & Vitaceae & V. vinifera \\
\hline Grapes (white) & Berry fruits & Italy & Vitaceae & V. vinifera \\
\hline Grapes (white) & Berry fruits & Spain & Vitaceae & $V$. vinifera \\
\hline Kiwi & Berry fruits & Italy & Actinidiaceae & Actinidia deliciosa \\
\hline Lemon & Berry fruits & Spain & Rutaceae & Citrus limon \\
\hline Lime & Berry fruits & Brazil & Rutaceae & Citrus aurantifolia \\
\hline Lychee & Stone fruits & RSA & Sapindaceae & Litchi chinensis Sonn. \\
\hline Mandarine Clementine & Berry fruits & Spain & Rutaceae & Citrus reticulata \\
\hline Mango & Stone fruits & Brazil & Anacardiaceae & Mangifera indica \\
\hline Mango & Stone fruits & Ecuador & Anacardiaceae & M. indica \\
\hline Melon Galia & Berry fruits & Brazil & Cucurbitaceae & Cucumis melo var. reticulatus \\
\hline Melon honeydew & Berry fruits & Brazil & Cucurbitaceae & C. melo \\
\hline Melon & Berry fruits & Brazil & Cucurbitaceae & C. melo \\
\hline Orange (Navel) & Berry fruits & Greece & Rutaceae & Citrus sinensis \\
\hline Orange (Navel) & Berry fruits & Spain & Rutaceae & C. sinensis \\
\hline Orange & Berry fruits & Spain & Rutaceae & C. sinensis \\
\hline Papaya & Berry fruits & Brazil & Caricaceae & Carica papaya \\
\hline Papaya & Berry fruits & Republic of Ivory Coast & Caricaceae & C. papaya \\
\hline Pear & Pip fruits & Poland & Rosaceae & Pyrus communis \\
\hline
\end{tabular}


Table 1 (continued)

\begin{tabular}{lllll}
\hline Product & Type of fruit & Origin & Botanical family & Scientific name \\
\hline Pear & Pip fruits & Italy & Rosaceae & P. communis \\
Pineapple & Accessory fruits & Costa Rica & Bromeliaceae & Ananas comosus \\
Pineapple & Accessory fruits & Honduras & Bromeliaceae & A. comosus \\
Plum & Stone fruits & Poland & Rosaceae & Prunus domestica \\
Raspberry & Accessory fruits & Poland & Rosaceae & Rubus idaeus \\
Redcurrant & Berry fruits & Poland & Grossulariaceae & Ribes rubrum \\
Strawberry_'Kashubian strawberry' & Accessory fruits & Poland & Rosaceae & Fragaria $\times$ ananassa Duchesne \\
\hline
\end{tabular}

Accuracy and precision of the analytical method used for quantification

The accuracy and precision of the method used for determination of the elements were confirmed by analysis of certified standard reference materials including tea (NCS DC 73351), cabbage (International Atomic Energy Agency (IAEA)-359) and spinach (IAEA331). NCS DC 73351 was purchased from the China National Analysis Centre for Iron and Steel, Beijing (China). CRM like cabbage (IAEA-359) and spinach (IAEA-331) were purchased from the IAEA, Vienna, Austria. Digestion of these materials was performed with the same decomposition procedure used for fresh fruits samples. Recoveries of the elements analysed varied between 85.5 and $103 \%$ and precisions for the reference materials were $0.13-6.08 \%$. All the results for the measurements of bioelements and toxic metals in reference materials are presented in Table 2.

\section{Statistics}

Correlation analysis, ANOVA Kruskal-Wallis test, factor analysis (FA) and cluster analysis (CA) of the data obtained were performed using STATISTICA 10.0 for Windows $\left(\right.$ Copyright $^{\odot}$ StatSoft, Inc. 19842011, USA). Before the chemometric analysis, the selected variables were tested for normality. In all cases, they did not follow the normal distribution according to the Shapiro-Wilk and KolmogorovSmirnov tests (Brereton 2003; Szefer 2007). Therefore, non-parametric procedures were adapted in our analyses. Prior the chemometric processing, the data matrix was standardised. As we rejected null hypothesis of the Kruskal-Wallis test, we applied post hoc test, i.e. Dunn test, which enabled us to highlight where the difference is by using multiple, stepdown comparisons.

The goal of FA is to find factors that represent common variance of features and explain the experimental

Table 2 Measurements of elements concentrations in reference materials

\begin{tabular}{|c|c|c|c|c|}
\hline Element & $\begin{array}{l}\text { Concentration } \\
\text { declared }(\mu \mathrm{g} / \mathrm{g})\end{array}$ & $\begin{array}{l}\text { Concentration } \\
\text { determined }(\mu \mathrm{g} / \mathrm{g})\end{array}$ & $\begin{array}{l}\text { Recovery } \\
(\%)\end{array}$ & $\begin{array}{l}\text { SD } \\
(\%)\end{array}$ \\
\hline $\mathrm{P}^{\mathrm{a}}$ & 2,840 & $2,900 \pm 166$ & 102 & 5.72 \\
\hline $\mathrm{P}^{\mathrm{b}}$ & 5,180 & $5,340 \pm 83.0$ & 103 & 1.55 \\
\hline $\mathrm{K}^{\mathrm{a}}$ & $16,600 \pm 1,200$ & $15,300 \pm 400$ & 92.2 & 2.61 \\
\hline $\mathrm{K}^{\mathrm{b}}$ & 32,500 & $27,785 \pm 850$ & 85.5 & 3.06 \\
\hline $\mathrm{Na}^{\mathrm{a}}$ & $44 \pm 6$ & $39.3 \pm 0.05$ & 89.3 & 0.13 \\
\hline $\mathrm{Mg}^{\mathrm{a}}$ & $1,700 \pm 200$ & $1,660 \pm 23.6$ & 97.7 & 1.42 \\
\hline $\mathrm{Mg}^{\mathrm{b}}$ & 2,160 & $2,110 \pm 35.6$ & 97.7 & 1.69 \\
\hline $\mathrm{Ca}^{\mathrm{b}, \mathrm{d}}$ & 18,500 & $18,450 \pm 96$ & 99.7 & 0.52 \\
\hline $\mathrm{Zn}^{\mathrm{a}}$ & $26.3 \pm 2.0$ & $25.5 \pm 1.55$ & 96.8 & 6.08 \\
\hline $\mathrm{Zn}^{\mathrm{b}}$ & 38.6 & $37.6 \pm 0.60$ & 97.3 & 1.60 \\
\hline $\mathrm{Fe}^{\mathrm{a}}$ & $264 \pm 15$ & $248 \pm 2.68$ & 93.9 & 1.08 \\
\hline $\mathrm{Fe}^{\mathrm{b}}$ & 148 & $137 \pm 5.49$ & 92.6 & 4.00 \\
\hline $\mathrm{Cu}^{\mathrm{a}}$ & $17.3 \pm 1.8$ & $16.2 \pm 0.76$ & 93.6 & 4.69 \\
\hline $\mathrm{Cu}^{\mathrm{b}}$ & 5.67 & $5.45 \pm 0.02$ & 96.1 & 0.37 \\
\hline $\mathrm{Mn}^{\mathrm{a}}$ & $1,240 \pm 70$ & $1,160 \pm 37.0$ & 93.5 & 3.19 \\
\hline $\mathrm{Mn}^{\mathrm{b}}$ & 31.9 & $32.5 \pm 0.66$ & 102 & 2.03 \\
\hline $\mathrm{Cr}^{\mathrm{a}}$ & $0.80 \pm 0.03$ & $0.77 \pm 0.02$ & 96.3 & 2.60 \\
\hline $\mathrm{Co}^{\mathrm{c}}$ & 0.39 & $0.38 \pm 0.00$ & 97.4 & 0.26 \\
\hline $\mathrm{Ni}^{\mathrm{a}}$ & $4.6 \pm 0.5$ & $4.15 \pm 0.03$ & 90.2 & 0.72 \\
\hline $\mathrm{Ni}^{\mathrm{b}}$ & 1.05 & $0.96 \pm 0.01$ & 91.4 & 1.04 \\
\hline
\end{tabular}

${ }^{\mathrm{a}}$ Tea (NCS DC 73351)

${ }^{\mathrm{b}}$ Cabbage (IAEA-359)

${ }^{\mathrm{c}}$ Spinach (IAEA-331)

${ }^{\mathrm{d}}$ Informative value 


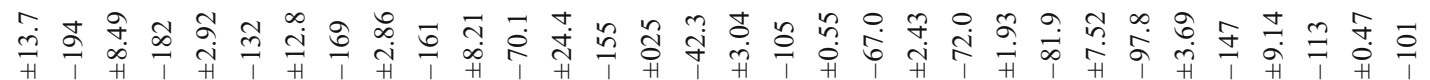

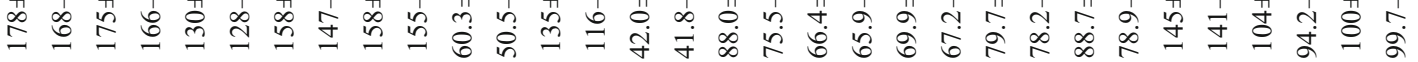

రำ

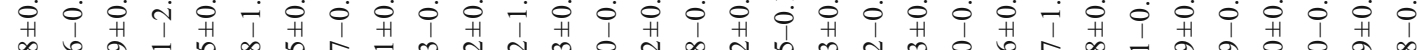
年

吕

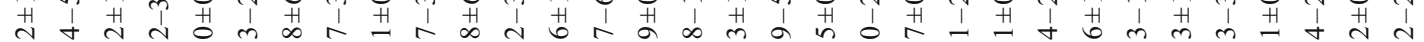

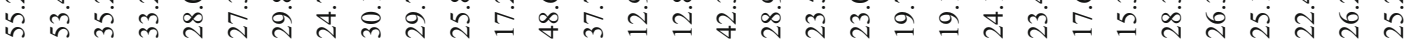

तิ

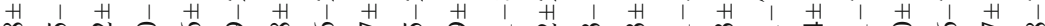

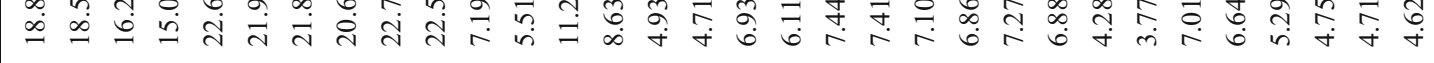

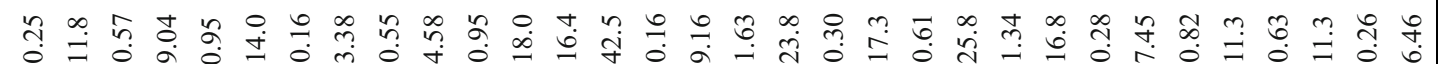

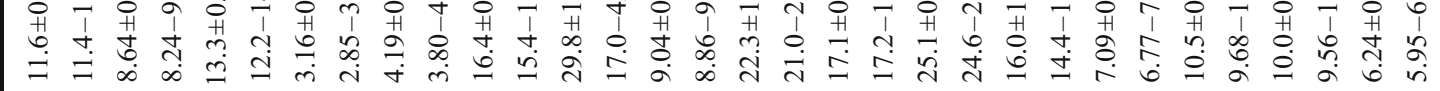

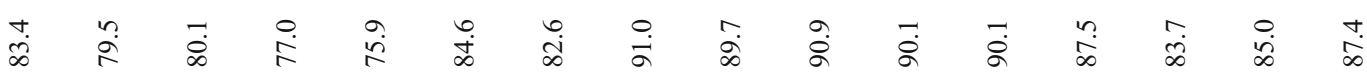

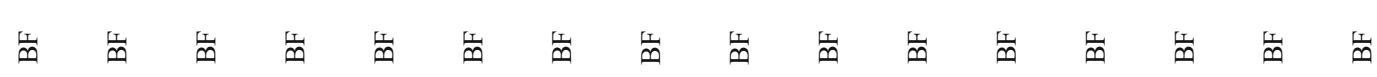
|

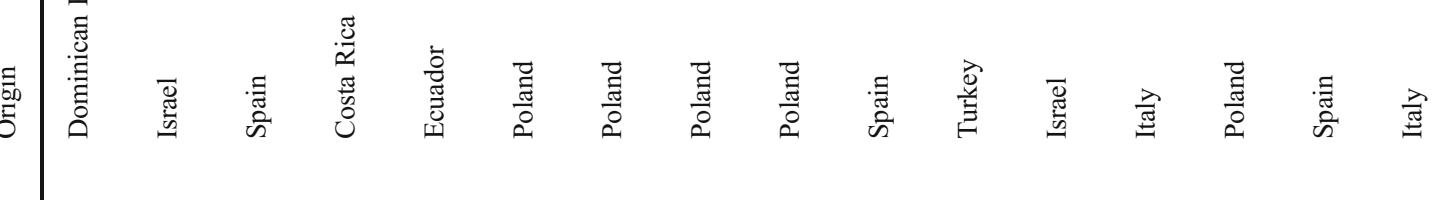




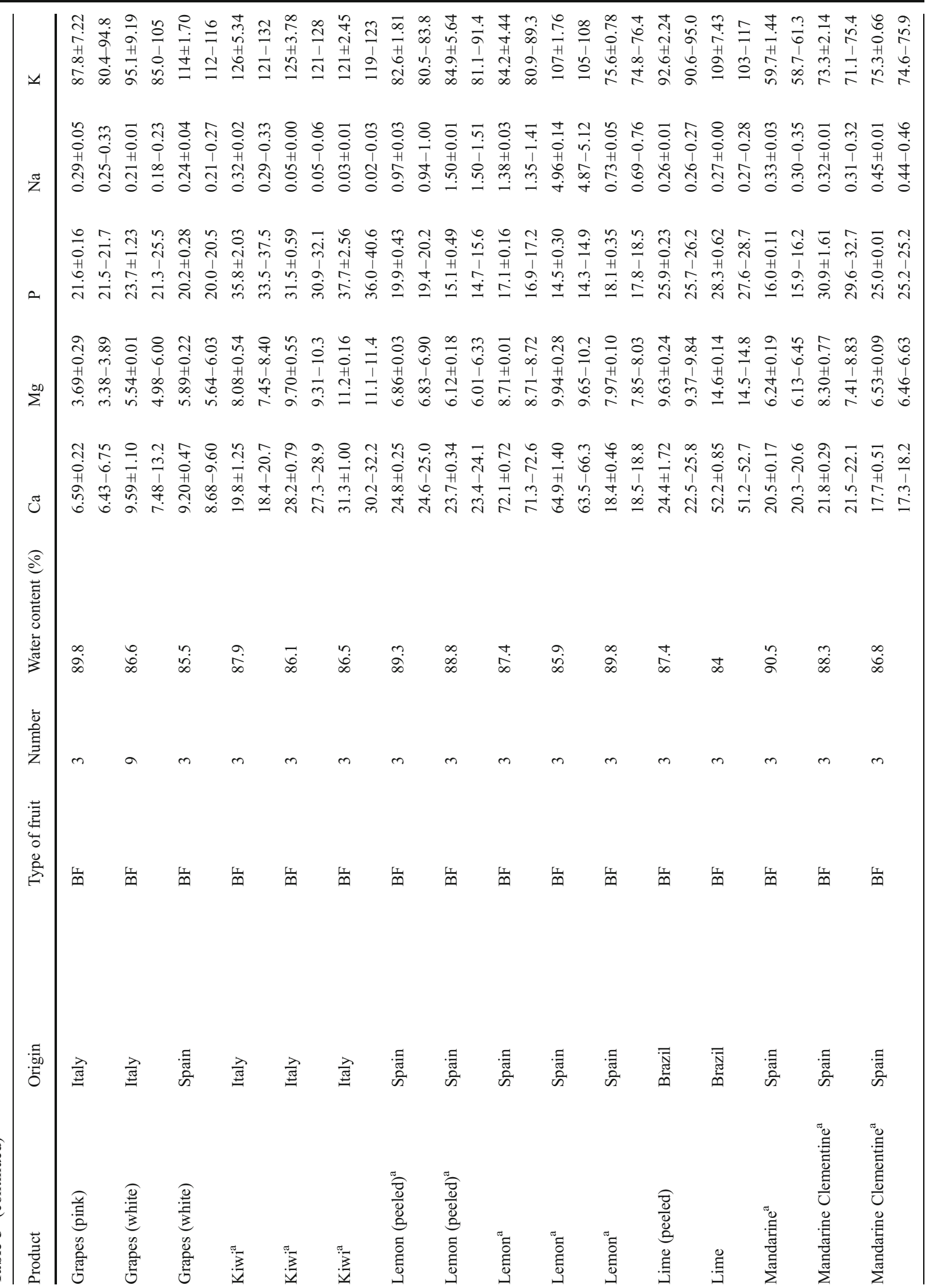




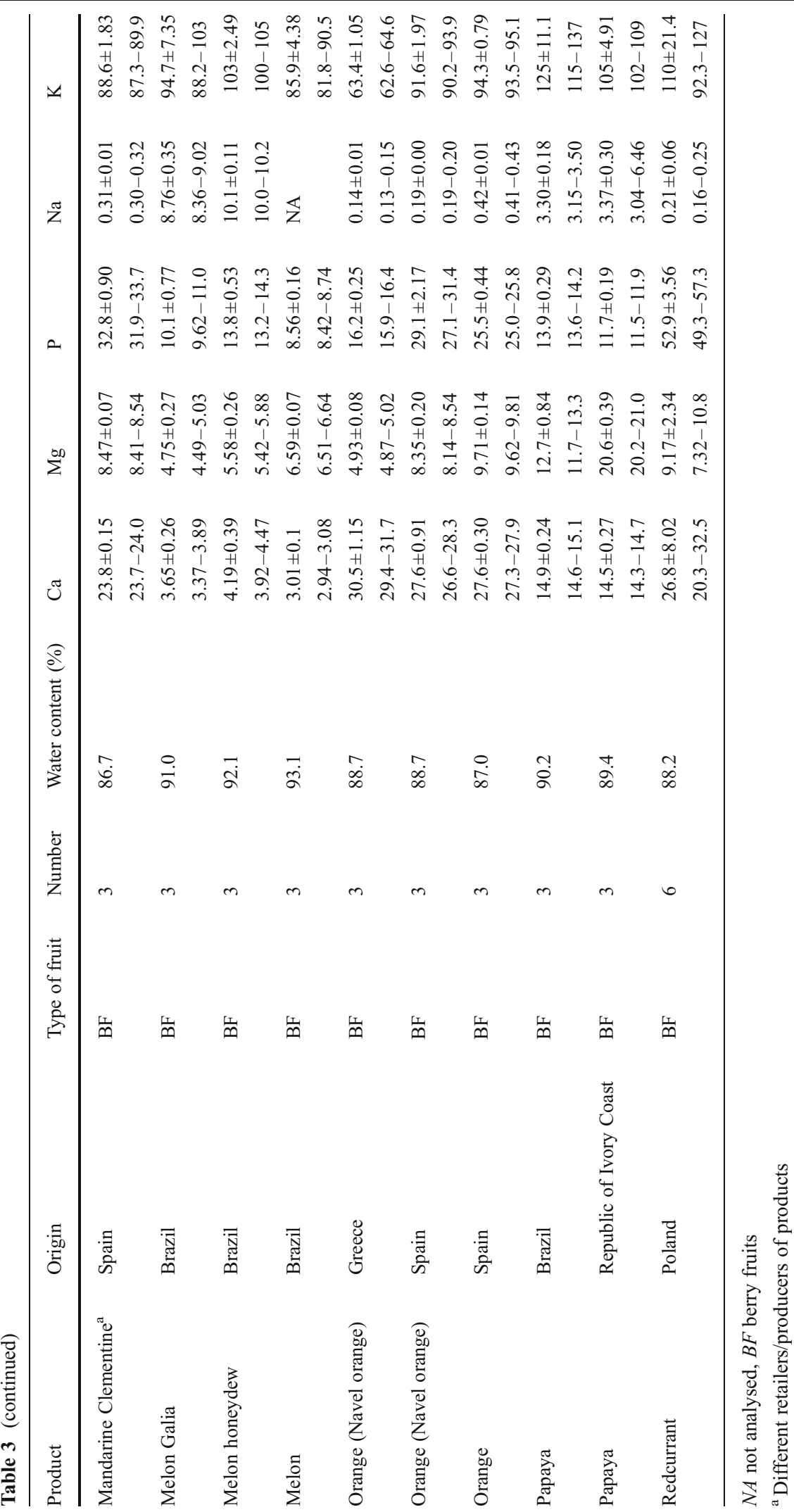




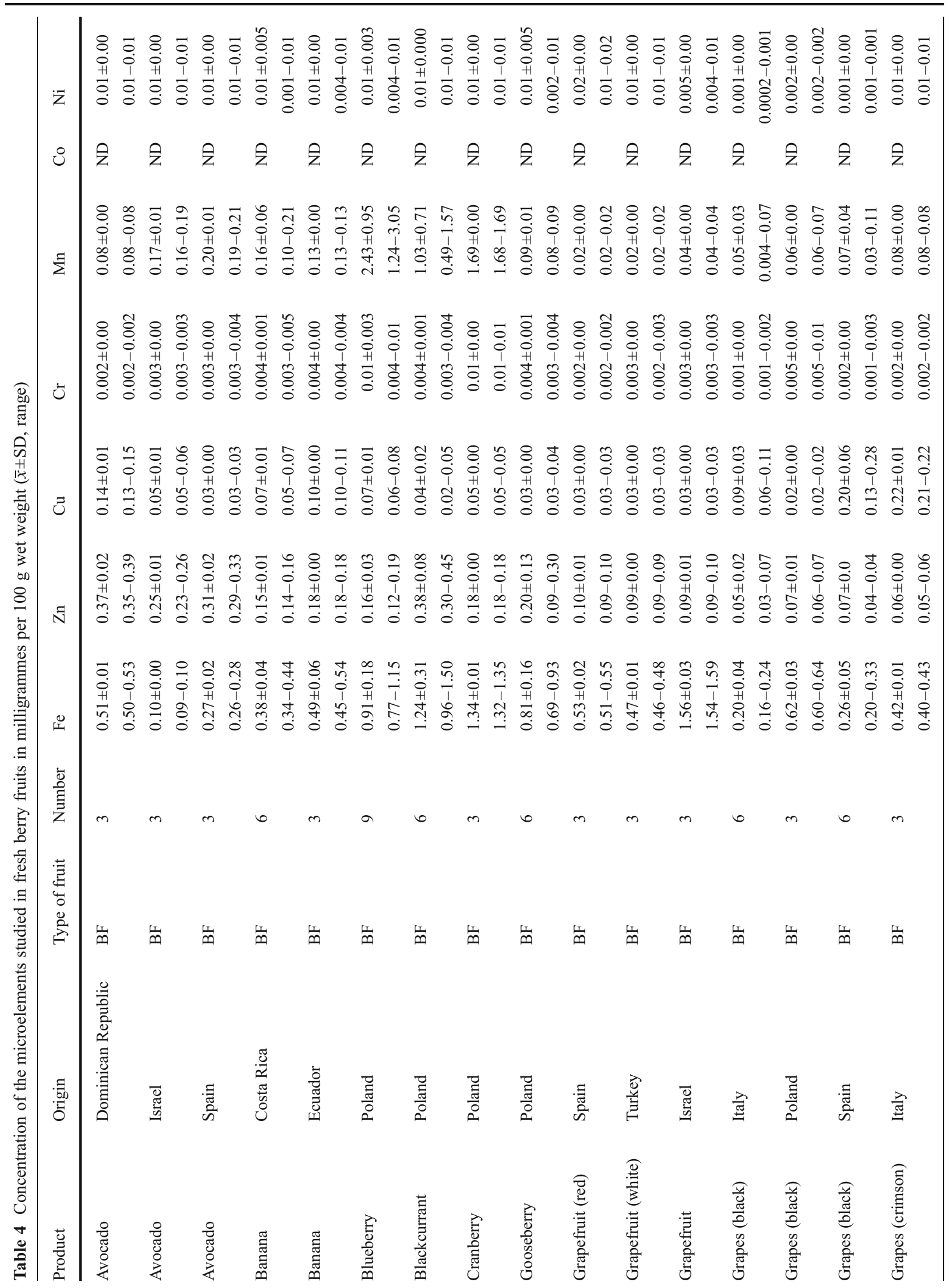




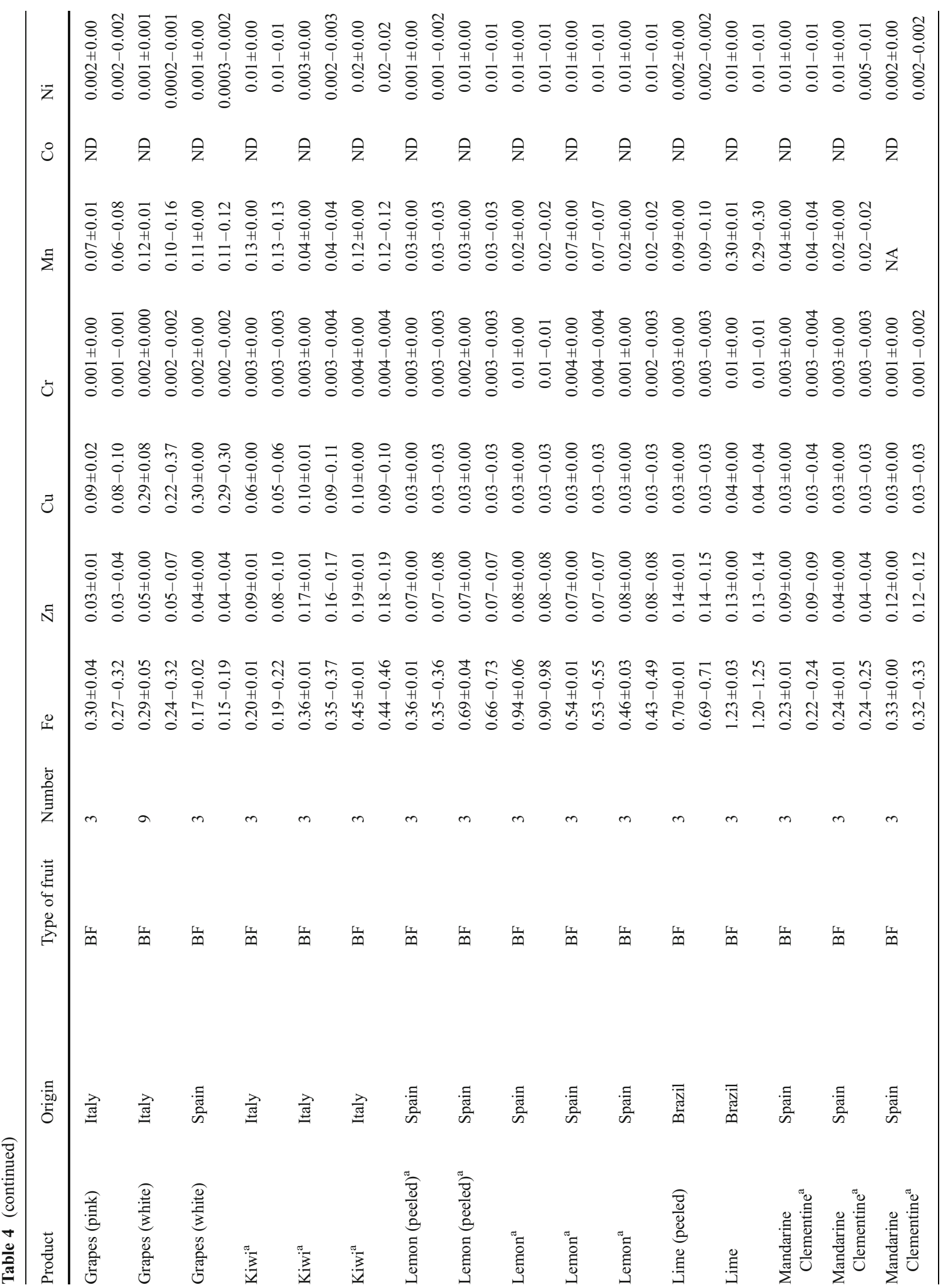




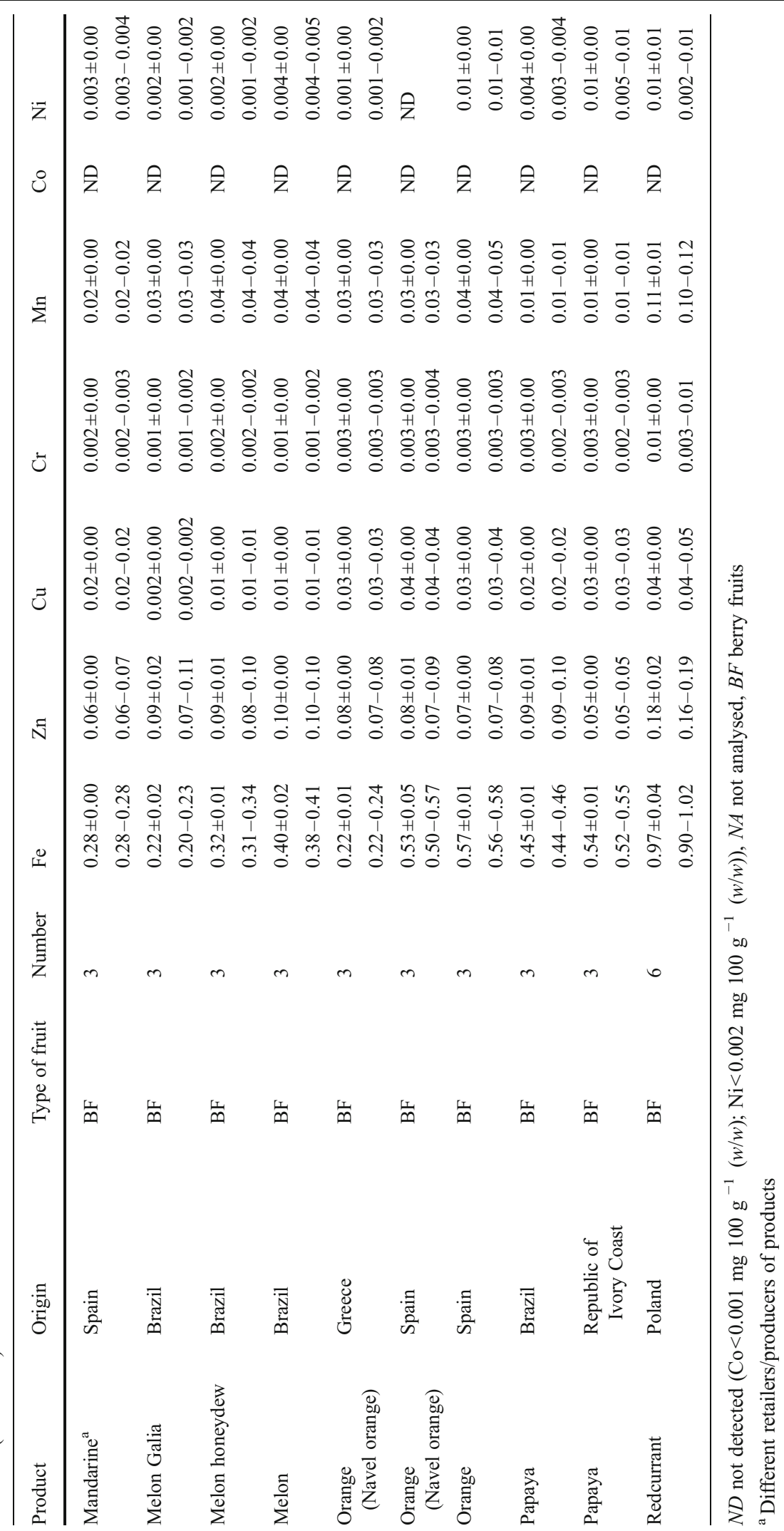


results. The total variance of the data is divided into three parts: common feature variance, specific feature variance and residuals or errors (Abollino et al. 2011). FA was performed on raw data sets concerning fresh fruits samples. Each products' arithmetic mean value of three subsamples was taken into consideration, therefore, 81 fresh fruits accounted for the final data matrix. The data matrix was established using the elements as columns and fruits samples as rows. Elements such as $\mathrm{Ni}$ and especially Co had to be eliminated from the data set because of their too low levels (mainly below detection limit (LOD)), therefore, nine loadings ( $\mathrm{Ca}, \mathrm{Mg}, \mathrm{Na}$, $\mathrm{K}, \mathrm{P}, \mathrm{Zn}, \mathrm{Cu}, \mathrm{Fe}$ and $\mathrm{Mn}$ ) constituted the ultimate data matrix. It is of particular importance to determine the number of factors in FA. There are several criteria for determining the number of factors, but in our study, we used Kaiser criterion and the Cattell scree test plot. According to the Kaiser rule is to drop all components with eigenvalues under 1 whereas Cattell's scree test plot says to drop all components after the one starting the elbow. Although three factors were defined but due to the fact that the variance explained by the third factor is very small, only two factors were taken into account when interpreting results. The cut-off loading value to determine which elements will be used at the clustering stage was set at the level $>0.70$.

CA, similarly to FA, was also performed on standardised raw data sets concerning fruit products. CA can be used to identify groups of similar samples and anomalous specimen; alternatively, the variables can be treated as objects and their similarity or dissimilarity can be investigated (Giacomino et al. 2011). The best results of CA analysis were obtained by applying the Ward method as a way of calculating cluster distances, as well as Euclidean distance as a measure of distance between analysed samples.

Results and discussion

Data of the elements analysed in fresh fruits samples are listed in the following tables: Tables 3 and 4, berry fruits; 5 , accessory fruits; 6 , pip fruits; and 7 , stone fruits. The metals concentrations in the samples are characterised by arithmetic mean value, the corresponding standard deviation (SD) and ranges for wet weight basis. As the original results were obtained for the dry mass they were recalculated based on the received data concerning water content which is also presented in Tables 3, 4, 5, 6 and 7. In case of some 


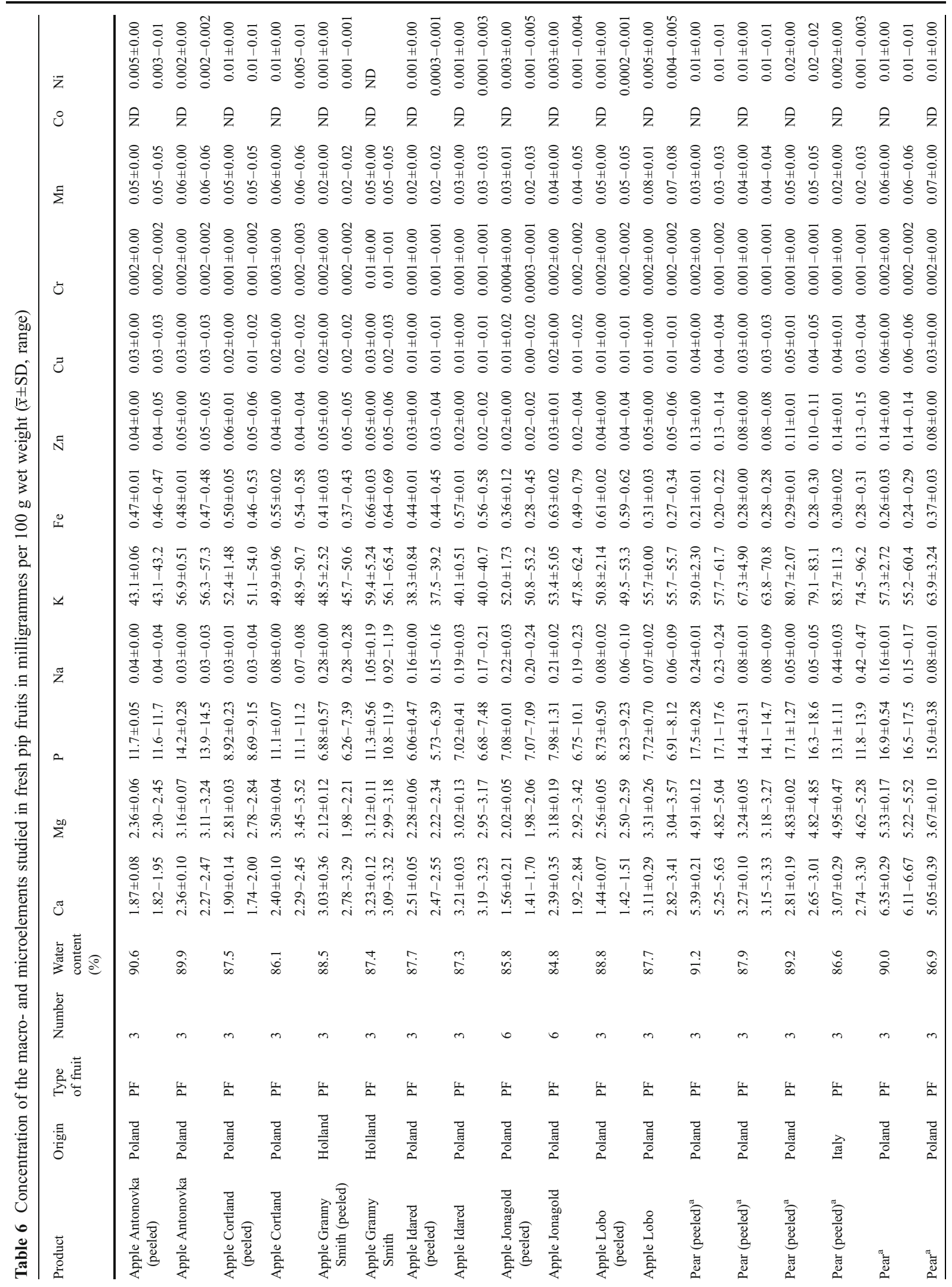


authors (Hamurcu et al. 2010; Plessi et al. 2007), we had to recalculate literature data to fresh weight based on the water content given by the author to make a comparison between our and literature data. If the cited author did not give such information, we used the water percentage assessed in our research in the case of the same type of fruits.

Co content in fruit samples was generally under LOD of the method applied $(\mathrm{Co}<0.001 \mathrm{mg} / 100 \mathrm{~g}$ $(w / w))$ but in case of $\mathrm{Ni}$ only two samples were below LOD $(\mathrm{Ni}<0.002 \mathrm{mg} / 100 \mathrm{~g}(w / w))$. The detection limit was established according to Konieczka and Namieśnik (2009), i.e. LD=blank mean+3 SD.

Macroelements

Mineral elements were found to vary widely among studied fruits. In general, peeled fruits (apples, lemons and pears) contained lower levels of macro- and microelements in comparison to unpeeled ones (Tables 3, 4, 5, 6 and 7). The most significant differences between these two types of samples were observed in the case of macroelements such as $\mathrm{Ca}, \mathrm{Mg}, \mathrm{P}$ and $\mathrm{K}$ (Tables 3, 5, 6 and 7). Their concentrations in the analysed samples were quite varied with the highest values for $\mathrm{K}$ (Tables 3, 5, 6 and 7). Ranges of $\mathrm{K}$ mean concentration in $100 \mathrm{~g}$ of fresh fruits samples were as follows: $55.7-131 \mathrm{mg}$ (accessory fruits), 41.8-178 mg (berry fruits), $38.3-83.7 \mathrm{mg}$ (pip fruits) and 57.8$141 \mathrm{mg}$ (stone fruits). Particularly rich in $\mathrm{K}$ were avocado (130-178 mg/100 g), banana (158 mg/100 g), cherry (98.3-127 mg/100 g) and kiwi (121$126 \mathrm{mg} / 100 \mathrm{~g}$ ) (Table 3, 5, 6 and 7). Average P levels determined in stone, accessory and berry fruits were comparable, i.e. $25.3,27.9$ and $26.9 \mathrm{mg} / 100 \mathrm{~g}$ of a product. The highest concentration of this element was determined in avocado from the Dominican Republic $(55.2 \mathrm{mg} / 100 \mathrm{~g})$ while the lowest in Idared apple $(6.06 \mathrm{mg} / 100 \mathrm{~g})$. Fruits characterised by higher levels of Mg were bananas (21.8-22.7 mg/100 g) and avocados $(16.2-22.6 \mathrm{mg} / 100 \mathrm{~g})$. Pip fruits contained the lowest amounts of the macroelements analysed whereas accessory fruits were particularly rich in $\mathrm{Mg}(31.0 \mathrm{mg} / 100 \mathrm{~g})$. Average $\mathrm{Na}$ levels in the analysed fruits were in the range of 0.1 (stone fruits) and $1.0 \mathrm{mg} / 100 \mathrm{~g}$ (berry fruits). The mean $\mathrm{Ca}$ concentration was the highest in berry fruits $(19.5 \mathrm{mg} / 100 \mathrm{~g})$ while the lowest in pip fruits $(3.2 \mathrm{mg} / 100 \mathrm{~g})$. Fruits absorb macroelements from the soil and in case of certain fruits such as avocado, banana 
or mango geographical origin seemed to have influence on their mineral composition (Tables 3 and 7).

These results concerning $\mathrm{P}$ in all types of fresh fruits analysed are comparable to findings of Souci et al. (2002) as well as Szefer and Grembecka (2007). However, Hardisson et al. (2001a) determined in papayas higher concentrations of $\mathrm{P}(17.9-20.5 \mathrm{mg} / 100 \mathrm{~g})$ and $\mathrm{K}$ (300-338 mg/100 g). According to Plessi et al. (2007), blackberries and black currants contain more $\mathrm{Mg}$, i.e. $150.92(23.2 \mathrm{mg} / 100 \mathrm{~g}$ fresh weight) and $106.73 \mathrm{mg} / 100 \mathrm{~g}$ dry weight $(18.6 \mathrm{mg} / 100 \mathrm{~g}$ fresh weight), respectively. Average $\mathrm{K}$ and $\mathrm{Mg}$ content for Hawaii's bananas was 330.6 and $35.1 \mathrm{mg} / 100 \mathrm{~g}$ fresh weight (Wall 2006) which is much higher than in our study. Similar values for $\mathrm{Mg}(27 \mathrm{mg} / 100 \mathrm{~g})$ and $\mathrm{K}$ $(358 \mathrm{mg} / 100 \mathrm{~g}$ ) in bananas can be found in Food Composition Table by McGraw-Hill Companies Staff (2008). Hardisson et al. (2001c) determined $\mathrm{K}$ in bananas in the range of $59-733 \mathrm{mg} / 100 \mathrm{~g}$. Hamurcu et al. (2010) analysed different kinds of fruits grown at the roadsides. They found comparable results for the analysed macroand microelements, i.e. plum contained 206.74 (32.5 mg/100 g fresh weight) and $4.21 \mathrm{mg} \mathrm{P} / 100 \mathrm{~g}$ dry weight $(0.66 \mathrm{mg} / 100 \mathrm{~g}$ fresh weight). Mitić et al. (2012) found higher levels of $\mathrm{Na}$ in sour cherries but comparable for $\mathrm{Mg}$ and $\mathrm{K}$ whereas lower for $\mathrm{Ca}$. According to McGraw-Hill Companies Staff (2008), cherries contain $14.3 \mathrm{mg} \mathrm{Ca}, 10 \mathrm{mg} \mathrm{Mg}$ and $214 \mathrm{mg}$ of $\mathrm{K}$ in $100 \mathrm{~g}$ fresh weight. Conventional mangoes samples contained on average $47.3 \mathrm{mg} \mathrm{Ca}, 146.6 \mathrm{mg} \mathrm{K}, 18.08 \mathrm{mg} \mathrm{Mg}$ and $11.44 \mathrm{mg} \mathrm{Na} / 100 \mathrm{~g}$ whereas organic ones $44.5 \mathrm{mg} \mathrm{Ca}$, $112 \mathrm{mg} \mathrm{K}, 17.96 \mathrm{mg} \mathrm{Mg}$ and $15.26 \mathrm{mg} \mathrm{Na} / 100 \mathrm{~g}$ (Hernández-Sánchez et al. 2012).

\section{Microelements}

Trace elements concentrations on wet basis are given in Tables 4, 5, 6 and 7. According to the results, Fe had the highest concentration followed by $\mathrm{Mn}$ and $\mathrm{Zn}$. The lowest $\mathrm{Fe}$ concentration was determined in avocado from Israel $-0.10 \mathrm{mg} / 100 \mathrm{~g}$ while the highest in grapefruit from Israel $-1.56 \mathrm{mg} / 100 \mathrm{~g}$. Accessory and stone fruits exhibited higher levels of $\mathrm{Fe}$ than the other fruits. Mn levels were in the range of 0.01 and $2.43 \mathrm{mg} / 100 \mathrm{~g}$ in papayas and blackberry, respectively (Tables 4, 5, 6 and 7). $\mathrm{Zn}$ concentration in the samples analysed ranged between 0.02 (apple Jonagold/Poland) and $0.44 \mathrm{mg} / 100 \mathrm{~g}$ (raspberry/Poland) (Table 4). The average concentrations of $\mathrm{Zn}$ were the highest in accessory fruits samples
$(0.20 \mathrm{mg} / 100 \mathrm{~g})$ while the lowest in pip fruits samples $(0.07 \mathrm{mg} / 100 \mathrm{~g})$. Cu levels in the samples analysed ranged from 0.001 to $0.30 \mathrm{mg} / 100 \mathrm{~g}$ (Tables 4, 5, 6 and 7).

In the case of $\mathrm{Ni}, \mathrm{Co}$ and $\mathrm{Cr}$, their average concentration was found to be the highest in accessory fruits, i.e. $0.02,0.01$ and $0.005 \mathrm{mg} / 100 \mathrm{~g}$, respectively (Table 5). Although accessory fruits were found to be the greatest source of $\mathrm{Ni}$ among all the analysed fruits, in all the fruits $\mathrm{Ni}$ was more abundant than $\mathrm{Cr}$ and $\mathrm{Co}$. The SDs of the mean values are quite low implying that the fruits analysed in this study were not highly contaminated by heavy metals.

Bagdatlioglu et al. (2010) presented similar values for $\mathrm{Cu}$ but lower for $\mathrm{Zn}$ in strawberries. Comparable average $\mathrm{Fe}$ concentration was determined by Plessi et al. (2007) in raspberries, i.e. $9.06 \mathrm{mg} / 100 \mathrm{~g}$ dry weight $(1.19 \mathrm{mg} / 100 \mathrm{~g}$ fresh weight). According to Food Composition and $\mathrm{Nu}-$ trition Tables by Souci et al. (2002), strawberries contain $0.26 \mathrm{mg} \mathrm{Zn}$ and $0.005 \mathrm{mg} \mathrm{Ni}$ while raspberries $0.36 \mathrm{mg} \mathrm{Zn}$ and $0.019 \mathrm{mg} \mathrm{Ni}$ in $100 \mathrm{~g}$ of fresh weight. Similar values are reported in Polish Food Composition Tables by Kunachowicz et al. (2005). Wall (2006) stated in her work that $\mathrm{Fe}, \mathrm{Cu}$ and $\mathrm{Mn}$ are of nutritional importance in bananas. On average they contain $0.78 \mathrm{mg} \mathrm{Fe} / 100 \mathrm{~g}$ and $0.49 \mathrm{mg} \mathrm{Mn} / 100 \mathrm{~g}$ (Wall 2006). Lower values for Fe $(0.16-0.54 \mathrm{mg} / 100 \mathrm{~g})$ and $\mathrm{Mn}(0.06-0.12 \mathrm{mg} / 100 \mathrm{~g})$ in bananas were determined by Hardisson et al. (2001c). Hamurcu et al. (2010) determined $\mathrm{Ni}$ and $\mathrm{Cr}$ concentration in plums that amounted to $0.050(0.008 \mathrm{mg} / 100 \mathrm{~g}$ fresh weight) and $0.027 \mathrm{mg} / 100 \mathrm{~g}$ dry weight $(0.004 \mathrm{mg} / 100 \mathrm{~g}$ fresh weight). Higher levels of $\mathrm{Fe}$, $\mathrm{Mn}$ and $\mathrm{Ni}$ and comparable for $\mathrm{Zn}$ and $\mathrm{Cr}$ were determined in table grapes by Mitić et al. (2012). According to Radwan and Salama (2006), apples contained 1.47 (0.02 mg Cu/100 g fresh weight) whereas bananas $2.51 \mathrm{mg} / 100 \mathrm{~g}$ dry weight $(0.06 \mathrm{mg} \mathrm{Cu} / 100 \mathrm{~g}$ fresh product) which is comparable to our results. The biggest $\mathrm{Cu}$ concentration was found in grapefruits, i.e. $7.75 \mathrm{mg} / 100 \mathrm{~g}$ dry weight $(0.09 \mathrm{mg} / 100 \mathrm{~g}$ fresh weight), which is three times higher than in our study (Radwan and Salama 2006). McGraw-Hill Companies Staff(2008) reported similar to that obtained in this study values for $\mathrm{Fe}$ and $\mathrm{Zn}$ in fruits. According to Hernández-Sánchez et al. (2012), conventional mangoes on average contain lower levels of $\mathrm{Fe}$ and $\mathrm{Cu}$ and higher of $\mathrm{Ni}$ and $\mathrm{Zn}$ than organic fruits. 


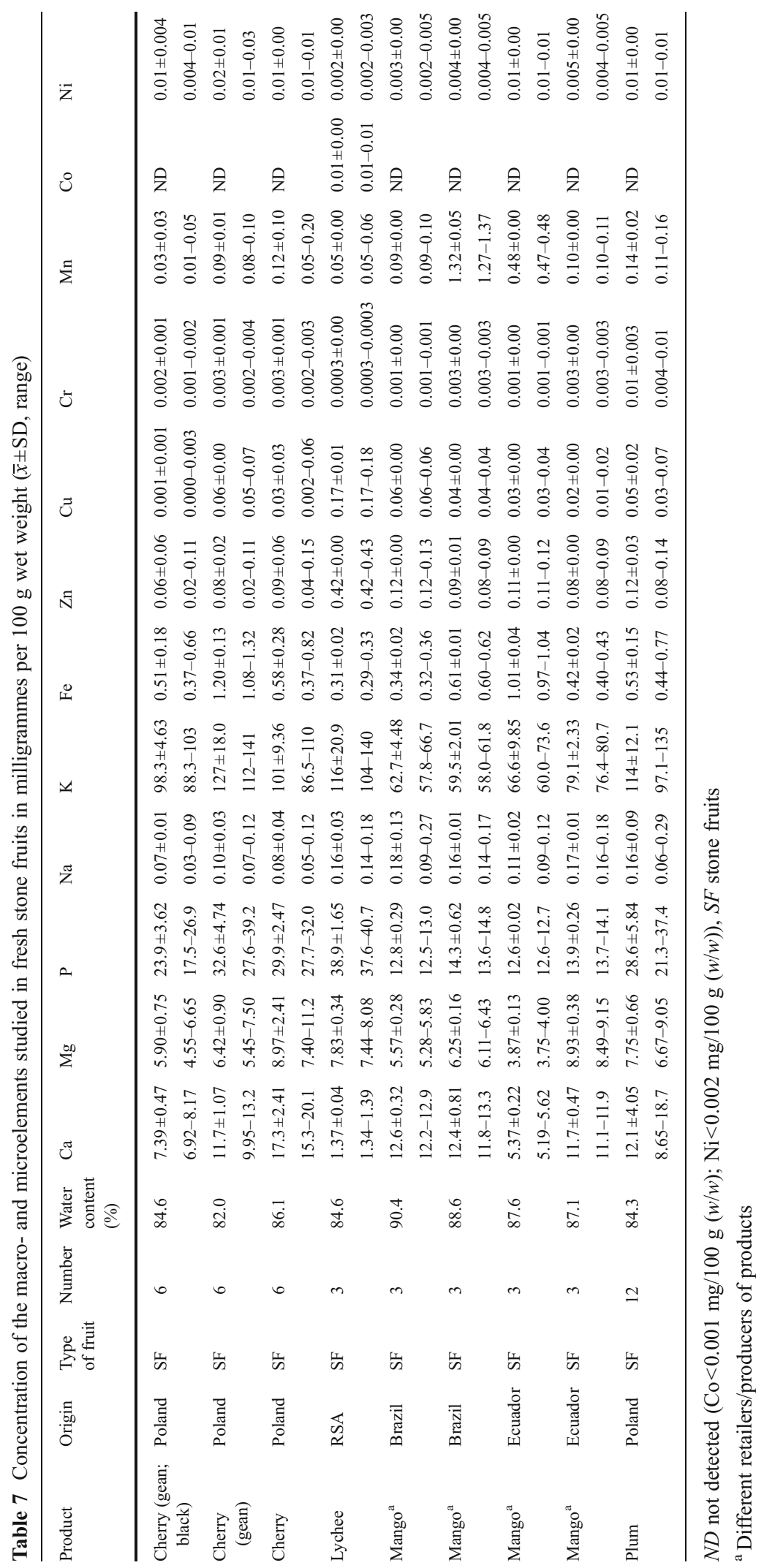


Table 8 Average realisation of recommended dietary allowance (RDA) and adequate intake (AI) values (in per cent) for macro- and microelements by $100 \mathrm{~g}$ of studied fruits

\begin{tabular}{|c|c|c|c|c|c|c|c|c|c|c|}
\hline & $\mathrm{P}$ & $\mathrm{Mg}$ & $\mathrm{Ca}$ & $\mathrm{K}$ & $\mathrm{Na}$ & $\mathrm{Fe}$ & $\mathrm{Zn}$ & $\mathrm{Cu}$ & $\mathrm{Mn}$ & $\mathrm{Cr}$ \\
\hline \multicolumn{11}{|c|}{ Microelements (mg person ${ }^{-1}$ day $^{-1}$ ) } \\
\hline Poland & 700 & $320(W) / 420(M)$ & $1,000^{\mathrm{a}}$ & $4,700^{\mathrm{a}}$ & $1,500^{\mathrm{a}}$ & $10(M) / 18(W)$ & $8(W) / 11(M)$ & 0.9 & - & - \\
\hline USA & 700 & $320(W) / 420(M)$ & 1,000 & $4,700^{\mathrm{a}}$ & $1,500^{\mathrm{a}}$ & $8(M) / 18(W)$ & $8(W) / 11(M)$ & 0.9 & $1.8(\mathrm{~W}) / 2.3(\mathrm{M})^{\mathrm{a}}$ & $\begin{array}{l}0.025(\mathrm{~W}) / 0.035 \\
(\mathrm{M})^{\mathrm{a}}\end{array}$ \\
\hline \multicolumn{11}{|c|}{$\%$ of RDA and $\mathrm{AI}$ realisation } \\
\hline $\begin{array}{l}\text { Accessory } \\
\text { fruits }\end{array}$ & 3.98 & $9.69-7.39$ & 1.65 & 1.92 & 0.02 & $7.09-3.94$ & $2.51-1.83$ & 6.28 & $35.3-27.7$ & $18.9-13.5$ \\
\hline Berry fruits & 3.84 & $2.96-2.26$ & 1.95 & 2.15 & 0.07 & $5.72-3.18$ & $1.61-1.17$ & 7.28 & $16.5-12.9$ & $12.6-8.98$ \\
\hline Pip fruits & 1.62 & $1.09-0.83$ & 0.32 & 1.24 & 0.01 & $4.24-2.36$ & $0.88-0.64$ & 2.96 & $2.56-2.00$ & $7.41-5.29$ \\
\hline Stone fruits & 3.62 & $2.21-1.68$ & 1.10 & 2.12 & 0.13 & $6.29-3.50$ & $1.47-1.07$ & 5.27 & $11.4-8.93$ & $11.7-8.34$ \\
\hline
\end{tabular}

RDA—entries set in italics

$W$ woman, $M$ man

${ }^{\mathrm{a}} \mathrm{AI}$

Recommended dietary intake

The daily mineral intake (in per cent) through consumption of $100 \mathrm{~g}$ of analysed fruits was calculated as $\mathrm{DMI}=\mathrm{C} \times 100 /$ recommended dietary allowance $(\mathrm{RDA}$; or adequate intake (AI)); where $\mathrm{C}$ - element concentration (in milligrammes) in $100 \mathrm{~g}$ fruits; RDA - according to the National Polish Food and Nutrition Institute (Jarosz and Bułhak-Jachymczyk 2008) or American data (Food and Nutrition Board 1997, 2001, 2005, 2011) if there was no Polish recommendation ( $\mathrm{Mn}$ and $\mathrm{Cr}$ ). Comparison of RDA and AI values for the analysed elements is presented in Table 8.
Consumption of $100 \mathrm{~g}$ of fresh fruits supplies the human body with varied amounts of mineral components (Table 8). In general, the average realisation of RDA and AI for an adult through consumption of $100 \mathrm{~g}$ of all studied fruits is between 3.06 and $4.01 \%$ for $\mathrm{Mg}, 1.28 \%$ for $\mathrm{Ca}$, $0.03 \%$ for $\mathrm{Na}, 1.92 \%$ for $\mathrm{K}, 3.39 \%$ for $\mathrm{P}, 1.12$ and $1.54 \%$ for $\mathrm{Zn}, 5.22 \%$ for $\mathrm{Cu}, 3.31$ and $5.95 \%$ for $\mathrm{Fe}, 11.8$ and $15.0 \%$ for $\mathrm{Mn}$ and 9.49 and $13.3 \%$ for $\mathrm{Cr}$. The highest average percentages of realisation of RDA and AI for an adult were obtained for accessory fruits, such as raspberries, strawberries and pineapples.
Table 9 Significant correlations between elements in fresh fruits

\begin{tabular}{ll}
\hline Element & Fruits \\
\hline $\mathrm{Mg}$ & $(+) \mathrm{P}^{\mathrm{c}},(+) \mathrm{Ca}^{\mathrm{c}},(+) \mathrm{K}^{\mathrm{c}},(+) \mathrm{Na}^{\mathrm{c}},(+) \mathrm{Zn}^{\mathrm{c}},(+) \mathrm{Cr}^{\mathrm{c}},(+) \mathrm{Mn}^{\mathrm{c}},(+) \mathrm{Ni}^{\mathrm{b}}$ and $(+) \mathrm{Cu}^{\mathrm{a}}$ \\
$\mathrm{Ca}$ & $(+) \mathrm{Mg}^{\mathrm{c}},(+) \mathrm{P}^{\mathrm{c}},(+) \mathrm{Cr}^{\mathrm{c}},(+) \mathrm{K}^{\mathrm{b}},(+) \mathrm{Zn}^{\mathrm{b}},(+) \mathrm{Ni}^{\mathrm{a}},(+) \mathrm{Na}^{\mathrm{a}}$ and $(+) \mathrm{Fe}^{\mathrm{a}}$ \\
$\mathrm{Na}$ & $(+) \mathrm{Mg}^{\mathrm{c}},(+) \mathrm{Ca}^{\mathrm{a}}$ and $(+) \mathrm{Cr}^{\mathrm{a}}$ \\
$\mathrm{K}$ & $(+) \mathrm{Mg}^{\mathrm{c}},(+) \mathrm{P}^{\mathrm{c}},(+) \mathrm{Ca}^{\mathrm{b}},(+) \mathrm{Zn}^{\mathrm{b}},(+) \mathrm{Cu}^{\mathrm{b}}$, and $(+) \mathrm{Cr}^{\mathrm{b}}$ \\
$\mathrm{P}$ & $(+) \mathrm{Mg}^{\mathrm{c}},(+) \mathrm{Ca}^{\mathrm{c}},(+) \mathrm{K}^{\mathrm{c}},(+) \mathrm{Zn}^{\mathrm{c}},(+) \mathrm{Cu}^{\mathrm{c}},(+) \mathrm{Cr}^{\mathrm{c}},(+) \mathrm{Mn}^{\mathrm{c}}$, and $(+) \mathrm{Ni}^{\mathrm{b}}$ \\
$\mathrm{Zn}$ & $(+) \mathrm{Mg}^{\mathrm{c}},(+) \mathrm{P}^{\mathrm{c}},(+) \mathrm{Cu}^{\mathrm{c}},(+) \mathrm{Cr}^{\mathrm{c}},(+) \mathrm{Ni}^{\mathrm{c}},(+) \mathrm{Mn}^{\mathrm{c}},(+) \mathrm{Ca}^{\mathrm{b}}$, and $(+) \mathrm{K}^{\mathrm{b}}$ \\
$\mathrm{Cu}$ & $(+) \mathrm{P}^{\mathrm{c}},(+) \mathrm{Zn}^{\mathrm{c}},(+) \mathrm{Mn}^{\mathrm{c}},(+) \mathrm{K}^{\mathrm{b}}$, and $(+) \mathrm{Mg}^{\mathrm{a}}$ \\
$\mathrm{Fe}$ & $(+) \mathrm{Cr}^{\mathrm{c}},(+) \mathrm{Mn}^{\mathrm{b}}$, and $(+) \mathrm{Ca}^{\mathrm{a}}$ \\
$\mathrm{Mn}$ & $(+) \mathrm{Mg}^{\mathrm{c}},(+) \mathrm{P}^{\mathrm{c}},(+) \mathrm{Zn}^{\mathrm{c}},(+) \mathrm{Cu}^{\mathrm{c}},(+) \mathrm{Cr}^{\mathrm{c}},(+) \mathrm{Fe}^{\mathrm{b}}$, and $(+) \mathrm{Ni}^{\mathrm{a}}$ \\
$\mathrm{Cr}$ & $(+) \mathrm{Mg}^{\mathrm{c}},(+) \mathrm{P}^{\mathrm{c}},(+) \mathrm{Ca}^{\mathrm{c}},(+) \mathrm{Fe}^{\mathrm{c}},(+) \mathrm{Zn}^{\mathrm{c}},(+) \mathrm{Mn}^{\mathrm{c}},(+) \mathrm{K}^{\mathrm{b}},(+) \mathrm{Na}^{\mathrm{a}}$, and $(+) \mathrm{Ni}^{\mathrm{a}}$ \\
$\mathrm{Ni}$ & $(+) \mathrm{Zn}^{\mathrm{c}},(+) \mathrm{Mg}^{\mathrm{b}},(+) \mathrm{P}^{\mathrm{b}},(+) \mathrm{Ca}^{\mathrm{a}},(+) \mathrm{Cr}^{\mathrm{a}}$, and $(+) \mathrm{Mn}^{\mathrm{a}}$ \\
\hline
\end{tabular}


Statistical estimate

\section{Correlation}

Statistically significant correlations $(\alpha<0.001, \alpha<0.01$ and $\alpha<0.05$ ) between concentrations of the metals studied in fresh fruits are listed in Table 9. As can be seen in Table 6, the majority of chemical elements exhibited significant positive correlations between their concentrations in the analysed samples. Significant positive relationships $(\alpha<0.001)$ were observed inter alia for the following assemblages: $\mathrm{Mg}-\mathrm{P}-\mathrm{Zn}, \mathrm{Na}-\mathrm{Mg}-\mathrm{Ca}$, $\mathrm{K}-\mathrm{Mg}-\mathrm{P}, \mathrm{Fe}-\mathrm{Cr}, \mathrm{Mn}-\mathrm{Mg}-\mathrm{P}$ and $\mathrm{Zn}-\mathrm{Cr}-\mathrm{Cu}-\mathrm{Mn}$.

\section{ANOVA Kruskal-Wallis test}

Due to the application of ANOVA Kruskal-Wallis, it was possible to record statistically significant influence of the botanical type of fruit (accessory, beery, pip and stone fruits) on the content of all macroelements and selected microelements (Table 10). There was statistically significant influence of type of fruit on a concentration of $\mathrm{P}, \mathrm{Mg}, \mathrm{Ca}, \mathrm{K}, \mathrm{Na}, \mathrm{Zn}, \mathrm{Cr}$ and $\mathrm{Mn}(\alpha<0.001)$ and $\mathrm{Cu}(\alpha<0.05)$.

Moreover, application of ANOVA Kruskal-Wallis test let us reveal statistically significant influence of the fruit's botanical provenance on the content of all the analysed macro- and microelements. The fruit's affinity to one of the following groups, i.e. Grossulariaceae, Actinidiaceae, Musaceae, Bromaeliaceae, Cucurbitaceae, Caricaceae, Anacardiaceae, Rosaceae, Rutaceae, Lauraceae, Vitaceae and Ericaceae, had an influence on $\mathrm{P}, \mathrm{Mg}, \mathrm{Ca}, \mathrm{K}, \mathrm{Na}, \mathrm{Zn}$, $\mathrm{Cu}$ and $\mathrm{Mn}(\alpha<0.001)$ and $\mathrm{Fe}$ and $\mathrm{Cr}$ content $(\alpha<0.01)$ (Table 10).

\section{FA and CA}

In order to visualise the data structure concerning fruit samples, a FA was carried out and the results depicted in Fig. 1a-c. $\mathrm{Ca}, \mathrm{Mg}, \mathrm{Na}, \mathrm{K}, \mathrm{P}, \mathrm{Zn}, \mathrm{Cu}, \mathrm{Fe}$ and $\mathrm{Mn}$ constituted the ultimate data matrix. The three factors (F1, F2 and F3) issued from FA explain cumulatively up to $58.7 \%$ of the total variance, so that $28.7 \%$ is explained by F1, $17.2 \%$ by F2 and $12.8 \%$ by F3. The eigenvalues are 2.87 (F1), 1.72 (F2) and 1.28 (F3), respectively. Figure 1a, b shows the factorial scatterplots for the studied samples. In order to identify elements responsible for the grouping of the objects, biplot of loadings was drawn for F1-F2 (Fig. 1c).

As can be observed on Fig. 1a several botanical families are well separated from each other. Higher values of F1 described by $\mathrm{P}, \mathrm{Zn}$ and $\mathrm{Cr}$ (Fig. 1c), correspond to Ericaceae, Grossulariaceae, Lauraceae and Actinidiaceae families. Its lower values characterise Cucurbitaceae samples rich in $\mathrm{Na}$. Groups of objects representing other fruits families are characterised by average values of $F 1$.

The lowest values of F2 correspond to Ericaceae samples, which mean that blackberries and cranberries are distinguished by $\mathrm{Mn}$ and Fe. Higher values of this factor are attributed to object samples representing Lauracea, Musaceae, Vitaceae and Cucurbitaceae which are identified by $\mathrm{Cu}, \mathrm{Zn}$ and $\mathrm{Fe}$.

Figure $1 \mathrm{~b}$ presents scatterplot of object scores for elements in fruits classified according to the fruit type, i.e. accessory, berry, pip and stone fruits. As can be seen in Fig. 1c, only the group of pip fruits corresponding to lower values of $\mathrm{F} 1$ and described by $\mathrm{Na}$ and $\mathrm{Cu}$ is well

Table 10 The influence of the fruit type and its botanical provenance on elemental composition in view of ANOVA Kruskal-Wallis test

\begin{tabular}{|c|c|c|c|c|c|c|c|c|c|c|c|}
\hline Fruits & $\mathrm{Mg}$ & $\mathrm{Ca}$ & $\mathrm{Na}$ & $\mathrm{K}$ & $\mathrm{P}$ & $\mathrm{Zn}$ & $\mathrm{Cu}$ & $\mathrm{Fe}$ & $\mathrm{Mn}$ & $\mathrm{Cr}$ & $\mathrm{Ni}$ \\
\hline Type accessory-berry-pip-stone & $50.8^{\mathrm{c}}$ & $43.4^{\mathrm{c}}$ & $22.6^{\mathrm{c}}$ & $34.4^{\mathrm{c}}$ & $32.6^{\mathrm{c}}$ & $16.5^{\mathrm{c}}$ & $9.89^{\mathrm{a}}$ & 6.13 & $25.8^{\mathrm{c}}$ & $25.3^{\mathrm{c}}$ & 4.49 \\
\hline Botanical provenance $^{\mathrm{d}}$ & $33.6^{\mathrm{c}}$ & $55.9^{\mathrm{c}}$ & $33.6^{\mathrm{c}}$ & $41.5^{\mathrm{c}}$ & $38.5^{\mathrm{c}}$ & $39.9^{\mathrm{c}}$ & 39.8 & $30.4^{\mathrm{b}}$ & $41.7^{\mathrm{c}}$ & $25.4^{\mathrm{b}}$ & $21.5^{\mathrm{a}}$ \\
\hline
\end{tabular}

The results are expressed as test value $(\mathrm{H})$

${ }^{\mathrm{a}} \alpha<0.05$

${ }^{\mathrm{b}} \alpha<0.01$

${ }^{\mathrm{c}} \alpha<0.001$

${ }^{\mathrm{d}}$ Grossulariaceae-Caricaceae-Vitaceae-Ericaceae-Anacardiaceae-Rosaceae-Actinidiaceae-Musaceae-Bromeliaceae-CucurbitaceaeRutaceae-Lauraceae 
distinguished from the others. In conclusion, FA allows on clear discrimination between pip and other types of fruits and F1 can be associated with differentiating fruits samples in view of their type.
Fig. 1 a Scatterplot of object scores of the two discriminant functions of fresh fruits samples classified according to their botanical family. b Scatterplot of object scores of the two discriminant functions of fresh fruits samples classified according to their fruits' type. c Scatterplot of loadings for 10 elements in fresh fruits samples

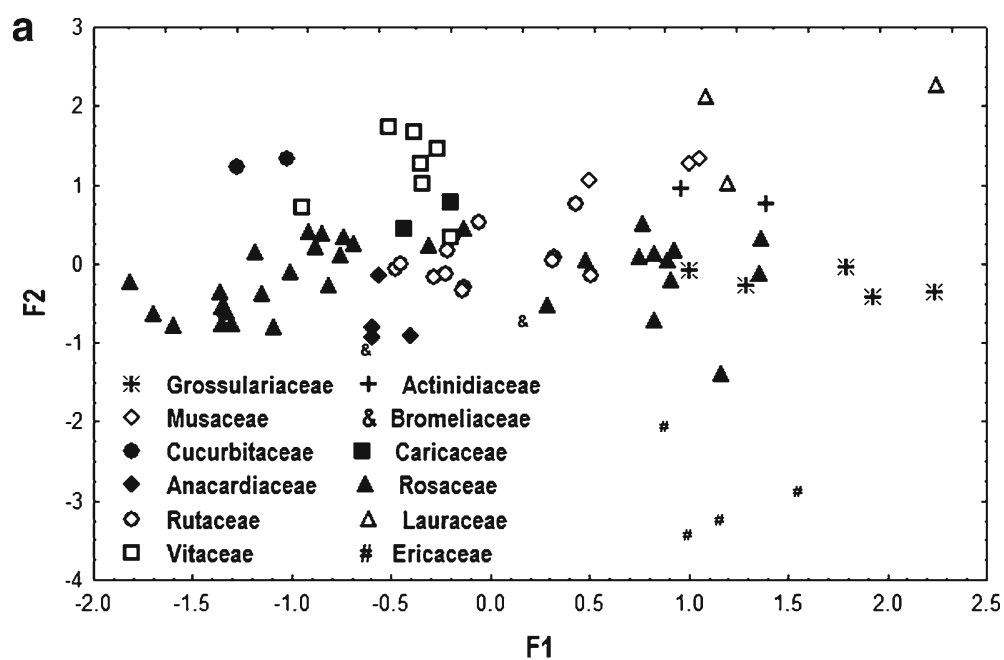

b
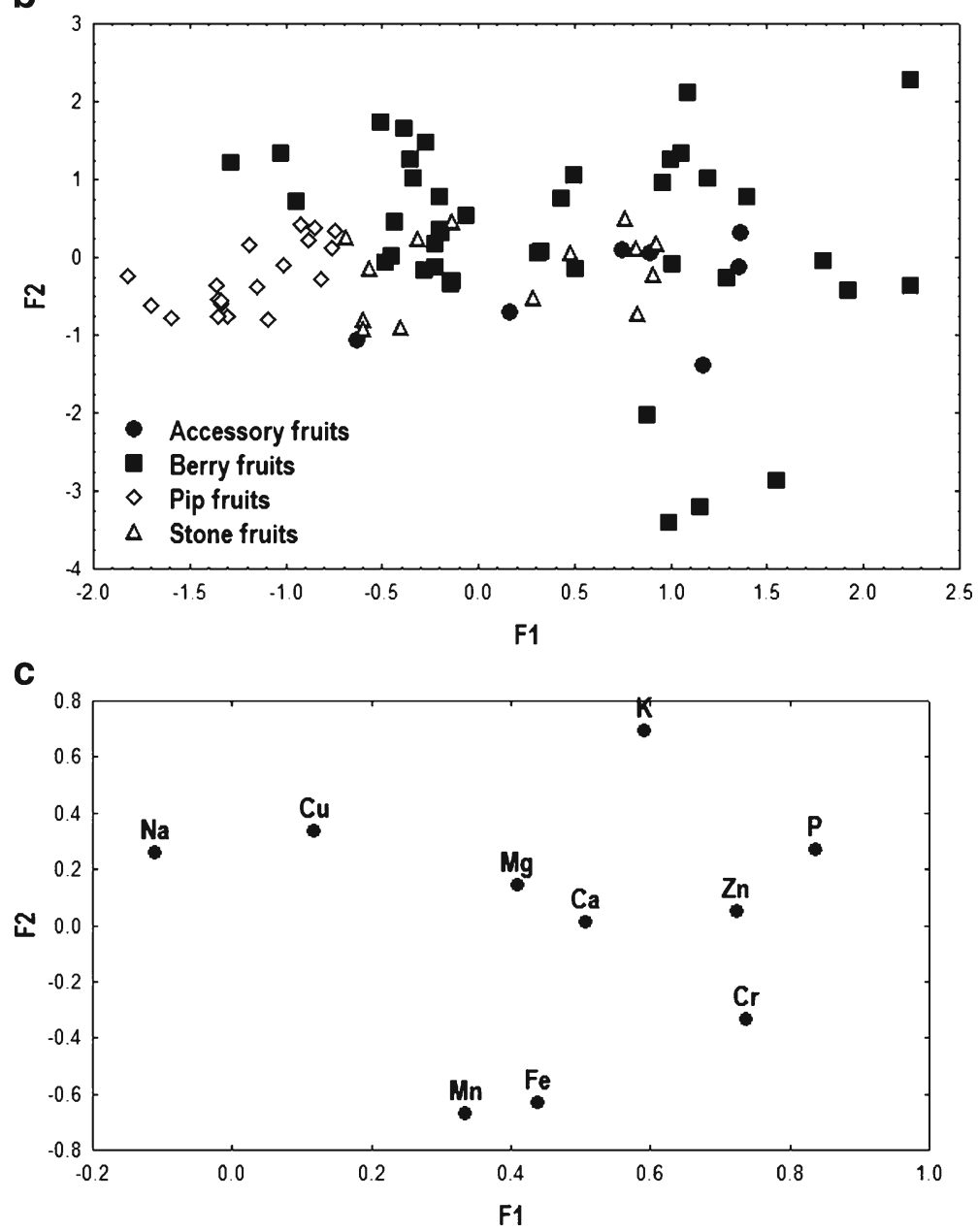
The CA data (hierarchical clustering, Ward's method) for fresh fruits as objects is shown in Fig. 2. CA aims at sorting different objects into groups in a way that the degree of association between two objects is maximal if they belong to the same group and minimal otherwise. The ultimate data matrix was composed of $\mathrm{Ca}, \mathrm{Mg}, \mathrm{Na}$, $\mathrm{K}, \mathrm{P}, \mathrm{Zn}, \mathrm{Cu}, \mathrm{Fe}$ and $\mathrm{Mn}$. As it can be seen on Fig. 2, there can be distinguished several clusters containing objects representing samples from the same botanical families. There are well-distinguished samples from Rosaceae, Rutaceae, Vitaceae, Musaceae, Caricaceae, Cucurbitaceae, Lauraceae, Actinidiaceae and Grossulariaceae families. The validity of the conclusions drawn from CA techniques is sometimes questioned since very different clusters can be formed from the same data depending on how the analysis is performed. However, in our case the results of CA in general confirm the outcome of FA. Therefore, it can be concluded that this technique is able, based on mineral composition, to distinguish samples not only of varied type but also in view of their botanical provenance.

\section{Conclusions}

As the literature is lacking thorough data concerning fresh fruits available on the market for consumers, we aimed to fulfil this gap. This study provides data on 12 elements concentration in fresh fruits available for consumers not only in Poland but also abroad as the products analysed were imported from other European countries, Africa, Asia and America. Fresh fruits proved to be products that are indispensable in our diet as they provide essential nutrients as $\mathrm{Mg}, \mathrm{K}, \mathrm{Ca}, \mathrm{P}$, $\mathrm{Zn}, \mathrm{Cu}, \mathrm{Fe}$ and $\mathrm{Mn}$. In general, peeled fruits (apples, lemons and pears) contained lower levels of macroand microelements in comparison to unpeeled ones, and the most significant differences were observed in the case of $\mathrm{Ca}, \mathrm{Mg}, \mathrm{P}$ and $\mathrm{K}$. There is no health hazard to consumers in view of heavy metals such as $\mathrm{Cu}, \mathrm{Ni}$ and $\mathrm{Cr}$ concentrations in the analysed samples. Based on RDA and AI estimated for essential elements, it was concluded that accessory fruits such as pineapples, raspberries and strawberries supply organism with the highest amounts of bioelements.

Based on the obtained results, it can be concluded that multivariate techniques are efficient tools that can be successfully applied to food quality and authenticity evaluation which are essential from the consumer's and producer's points of view. In this paper loadings such as $\mathrm{Ca}, \mathrm{Mg}, \mathrm{Na}, \mathrm{K}, \mathrm{P}, \mathrm{Zn}$, $\mathrm{Cu}, \mathrm{Fe}, \mathrm{Cr}$ and $\mathrm{Mn}$ were good descriptors for different kinds of fresh fruits. Their application was helpful for the deeper understanding of the distribution of selected metals in food.
Fig. 2 Hierarchical dendrogram for fresh fruits samples as objects $(G R$

Grossulariaceae, $A C$

Actinidiaceae, $M U$

Musaceae, $B R$

Bromeliaceae, $C U$

Cucurbitaceae, $C A$

Caricaceae, $A N$

Anacardiaceae, $R O$

Rosaceae, $R U$ Rutaceae, $L A$ Lauraceae, $V I$ Vitaceae, ER Ericaceae)

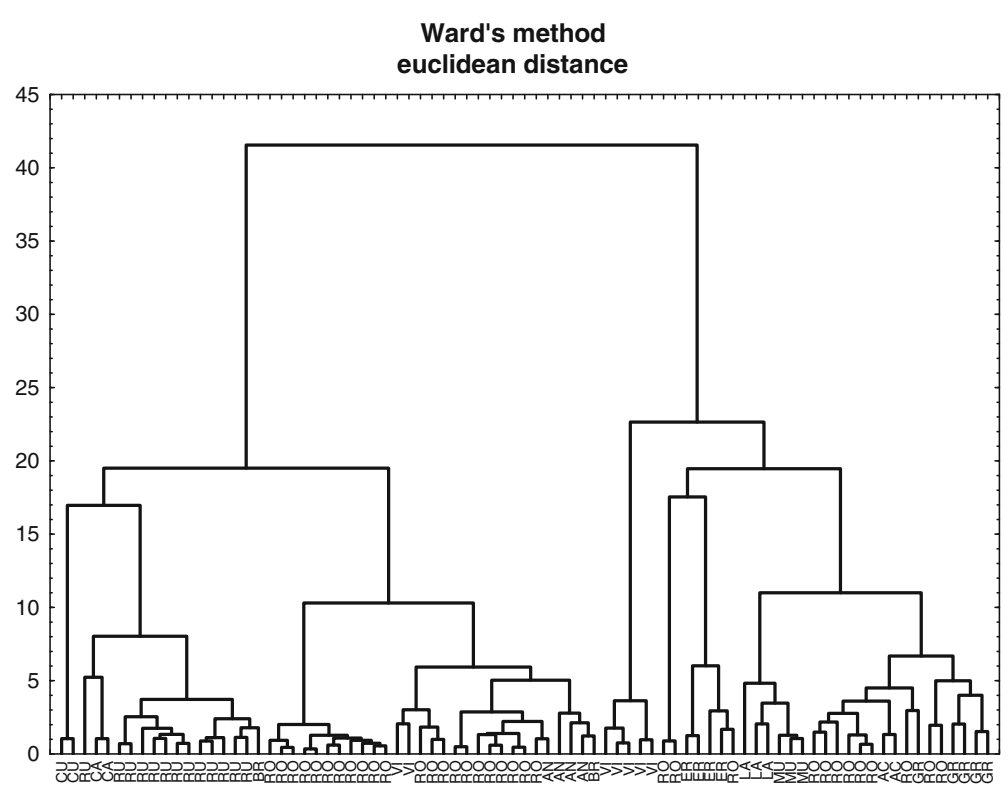


Application of ANOVA Kruskal-Wallis test lets us reveal dependence between biological provenance of the fruits as well as their type and elemental composition. The employed chemometric techniques such as factor and cluster analyses have proved to be reliable tools in differentiation of fruits in view of their mineral composition.

Open Access This article is distributed under the terms of the Creative Commons Attribution License which permits any use, distribution, and reproduction in any medium, provided the original author(s) and the source are credited.

\section{References}

Abollino, O., Malandrino, M., Giacomino, A., \& Mentasti, E. (2011). The role of chemometrics in single and sequential extraction assays: a review. Part I. Extraction procedures, uni- and bivariate techniques and multivariate variable reduction techniques for pattern recognition. Analytica Chimica Acta, 688, 104-121.

Arvanitoyannis, I. S., \& van Houwelingen-Koukaliaroglou, M. (2003). Implementation of chemometrics for quality control and authentication of meat and meat products. Critical Reviews in Food Science and Nutrition, 43, 173-218.

Bagdatlioglu, N., Nergiz, C., \& Ergonul, P. G. (2010). Heavy metals levels in leafy vegetables and some selected fruits. Journal für Verbraucherschutz und Lebensmittelsicherheit, 5, 421-428.

Brereton, R. G. (2003). Chemometrics: data analysis for the laboratory and chemical plant. Chichester: Wiley.

European Union (2007) Commission Regulation (EC) No. 1580/2007 of 21 December 2007. http://eurlex.europa.eu/ LexUriServ/LexUriServ.do?uri=OJ:L:2007:350:0001: 0098:EN:PDF. Accessed 14th December 2011

FAOSTAT (2010). http://faostat.fao.org/site/339/default.aspx. Accessed 6th April 2012.

Food and Nutrition Board (1997). DRI Dietary reference intakes for calcium, phosphorus, magnesium, vitamin D, and fluoride. Washington, DC: The National Academies Press. http://www.nap.edu/openbook.php?record_id=5776

Food and Nutrition Board (2001). Dietary reference intakes for vitamin a, vitamin $k$, arsenic, boron, chromium, copper, iodine, iron, manganese, molybdenum, nickel, silicon, vanadium, and zinc. Washington, DC: The National Academies Press. http://www.nap.edu/openbook.php?isbn=0309072794

Food and Nutrition Board (2005). Dietary reference intakes for water, potassium, sodium, chloride, and sulfate. Washington, DC: The National Academies Press. http:// www.nap.edu/openbook.php?isbn=0309091691

Food and Nutrition Board (2011). DRI dietary reference intakes calcium vitamin D. Washington, DC: The National Academies Press. http://books.nap.edu/ openbook.php?record_id $=13050$

Giacomino, A., Abollino, Ō., Malandrino, M., \& Mentasti, E. (2011). The role of chemometrics in single and sequential extraction assays: a review. Part II. Cluster analysis, multiple linear regression, mixture resolution, experimental design and other techniques. Analytica Chimica Acta, $688,122-139$.

Grembecka, M., \& Szefer, P. (2011). Metals and metalloids in foods: essentiality, toxicity, applicability. In D. A. Medina \& A. M. Laine (Eds.), Food quality: control, analysis and consumer concerns (pp. 1-60). Hauppauge: Nova Science Publishers.

Grembecka, M., Malinowska, E., \& Szefer, P. (2007). Differentiation of market coffee and its infusions in view of their mineral composition. Science of the Total Environment, $383,59-69$.

Habauzit, V., \& Horcajada, M.-N. (2008). Phenolic phytochemicals and bone. Phytochemistry Reviews, 7, 313-344.

Hamurcu, M., Özcan, M. M., Dursun, N., \& Gezgin, S. (2010). Mineral and heavy metals levels in some fruits grown at the roadsides. Food and Chemical Toxicology, 48(6), 17671770.

Hardisson, A., Rubio, C., Báez, A., Martin, M., \& Alvarez, R. (2001a). Mineral composition of the papaya (Carica papaya variety sunrise) from Tenerife island. European Food Research and Technology, 212, 175-181.

Hardisson, A., Rubio, C., Báez, A., Martin, M., \& Alvarez, R. (2001b). Mineral composition in four varieties of avocado (Persea gratissima, L.) from the island of Tenerife. European Food Research and Technology, 213, 225-230.

Hardisson, A., Rubio, C., Báez, A., Martin, M., Alvarez, R., \& Diaz, E. (2001c). Mineral composition of the banana (Musa acuminata) from the island of Tenerife. Food Chemistry, 73, 153-161.

Hernández-Sánchez, C., Luis, G., Moreno, I., Cameán, A., González, A. G., González-Weller, D., Castilla, A., Gutiérrez, A., Rubio, C., \& Hardisson, A. (2012). Differentiation of mangoes (Magnifera indica L.) conventional and organically cultivated according to their mineral content by using support vector machines. Talanta, 97, 325-330.

Hui, Y. H., Barta, J., Cano, M. P., Gusek, T. W., Sidhu, J. S., \& Sinha, N. K. (2006). Handbook of Fruits and Fruit Processing. USA: Wiley-Blackwell.

Husain, A., Baroon, Z., Al-khalafawi, M., Al-Ati, T., \& Sawaya, W. (1995). Toxic metals in imported fruits and vegetables marketed in Kuwait. Environment International, 6, 803-805.

IARC Monographs (2012). Arsenic, metals, fibres and dusts. Volume 100C. A review of human carcinogens. http:// monographs.iarc.fr/ENG/Monographs/vol100C/ mono100C.pdf. Accessed 5th March 2013

Jarosz, M., \& Bułhak-Jachymczyk, B. (2008). Normy żywienia człowieka. Podstawy prewencji otyłości i chorób niezakaźnych. Warszawa: PZWL (in Polish).

Jiang, Y., Song, J., Hui, Y. H., Chen, F., Nollet, L. M., Guiné, R. P. F., Martín-Belloso, O., Mínquez-Mosquera, M. I., Paliyath, G., Pessoa, F. L. P., Le Quéré, J.-L., Sidhu, J. S., \& Sinha, N. (2010). Fruits and fruit flavor: classification and biological characterization. In P. Stanfield (Ed.), Handbook of fruit and vegetable flavors (pp. 3-24). New York: Wiley.

Kay, C. D., Kris-Etherton, P. M., \& West, S. G. (2006). Effects of antioxidant-rich foods on vascular reactivity: review of the clinical evidence. Current Atherosclerosis Reports, 8, 510-522. 
Konieczka, P., \& Namieśnik, J. (2009). Quality assurance and quality control in the analytical chemical laboratory: a practical approach. Boca Raton: CRC Press.

Kunachowicz, H., Nadolna, I., Przygoda, B., \& Iwanow, K. (2005). Tables of nutritional value of food products and dishes. Warszawa: PZWL (in Polish).

Lane, P. W. (2002). Generalized linear models in soil science. European Journal of Soil Science, 53, 241-251.

Lecerf, J.-M. (2008). Fruits et prévention de l'ostéoporose. Phytothérapie, 6, 103-107.

McGraw-Hill Companies Staff, (2008). Food Composition Table. McGraw-Hill Higher Education, USA. http:// highered.mcgraw-hill.com/sites/dl/free/0073522732/ 578595/food_comp_table.pdf. Accessed 10th March 2013

Mitić, S. S., Obradović, M. V., Mitić, M. N., Kostić, D. A., Pavlović, A. N., Tošić, S. B., \& Stojković, S. D. (2012). Elemental composition of various sour cherry and table grape cultivars using inductively coupled plasma atomic emission spectrometry method (ICP-OES). Food Analytical Methods, 5, 279-286.

Moreda-Pineiro, A., Fisher, A., \& Hill, S. J. (2003). The classification of tea according to region of origin using pattern recognition techniques and trace metal data. Journal of Food Composition and Analysis, 16, 195-211.

Nabrzyski, M. (2007). Functional role of some minerals in foods. In P. Szefer \& J. O. Nriagu (Eds.), Mineral components in foods (pp. 363-388). London: CRC Press.

Nosecka, B. (2010). The market of fruits, vegetables and their processed products in Poland. Polish Food, Summer: 9-12

Official Methods of Analysis of AOAC International. (2002). Official method 991.25. Calcium, magnesium, and phosphorus in cheese-atomic absorption spectrophotometric and colorimetric method (17th ed.). Gaithersburg, MD, USA: AOAC International. Rev 1.

Park, B., Shin, A., Park, S. K., Ko, K.-P., Ma, S. H., Lee, E.-H., Gwack, J., \& Jung, E.-J. (2011). Ecological study for refrigerator use, salt, vegetable, and fruit intakes, and gastric cancer. Cancer Causes \& Control, 22, 1497-1502.

Pillonel, L., Badertscher, R., Froidevaux, P., Haberhauer, G., Holzl, S., Horn, P., Jakob, A., Pfammatter, E., Piantini, U., Rossmann, A., Tabacchi, R., \& Bosset, J. O. (2003). Stable isotope ratios, major, trace and radioactive elements in emmental cheeses of different origins. LebensmittelWissenschaft und Technologie, 36, 615-623.

Plessi, M., Bertelli, D., \& Albasini, A. (2007). Distribution of metals and phenolic compounds as a criterion to evaluate variety of berries and related jams. Food Chemistry, 100, 419-427.

Radwan, M., \& Salama, A. K. (2006). Market basket survey for some heavy metals in Egyptian fruits and vegetables. Food and Chemical Toxicology, 44, 1273-1278.

Souci, S. W., Fachmann, W., \& Kraut, H. (2002). Food composition and nutrition tables. Stuttgart: Scientific Publishers.

Szefer, P. (2003). Application of chemometric techniques in analytical evaluation of biological and environmental samples. In J. Namieśnik, W. Chrzanowski, \& P. Żmijewska (Eds.), New horizons and challenges in environmental analysis and monitoring. Gdańsk: CEEAM.

Szefer, P. (2007). Chemometric techniques in analytical evaluation of food quality. In P. Szefer \& J. O. Nriagu (Eds.), Mineral components in foods. Boca Raton: CRC Press.

Szefer, P., \& Grembecka, M. (2007). Mineral components in food crops, beverges, luxury food, spices, and dietary food. In P. Szefer \& J. Nriagu (Eds.), Mineral components in food. Boca Raton: CRC Press.

The Ministry of Agriculture and Rural Development of Poland (2010). Quality tradition — national system of high quality products. Polish Food, Summer: 16-17.

Tucker, K. L. (2009). Osteoporosis prevention and nutrition. Current Osteoporosis Reports, 7, 111-117.

Wall, M. M. (2006). Ascorbic acid, vitamin A and mineral composition of banana (Musa sp.) and papaya (Carica papaya) cultivars grown in Hawaii. Journal of Food Composition and Analysis, 19, 434-445.

Webster, R. (2001). Statistics to support soil research and their presentation. European Journal of Soil Science, 52, 331-340.

Webster, R. (2007). Analysis of variance, inference, multiple comparisons and sampling effects in soil research. European Journal of Soil Science, 58, 74-82.

Webster, R., \& Payne, R. W. (2002). Analysing repeated measurements in soil monitoring and experimentation. European Journal of Soil Science, 53, 1-13. 